\title{
Experimental investigation and optimization of HCCI engine fueled by isopropanol and heptane mixture
}

\author{
Seyed Mohammad Safieddin Ardebili ${ }^{*}$, Çağatay Nacak ${ }^{2}$, Tolga Kocakulak³ ${ }^{3}$ Mustafa Babagiray ${ }^{4}$
}

${ }^{1}$ Turkey Department of Biosystems Engineering, Shahid Chamran University of Ahvaz, Ahvaz, Iran
${ }^{2}$ Automotive Engineering Department, Faculty of Technology, Gazi University, Ankara, 06500
${ }^{3}$ Electricity and Energy Department, Vocational High School of Technical Sciences, Burdur Mehmet Akif Ersoy University, Burdur,
15030 , Turkey
${ }^{4}$ Automotive Engineering Department, Faculty of Technology, Afyon Kocatepe University, Afyonkarahisar, 03200, Turkey

\section{ABSTRACT}

Nowadays optimization is increasing in experiments on the engine tests studies. In this study, the test fuel obtained by mixing isopropanol with $\mathrm{n}$-heptane fuel under various engine conditions in HCCI mode was examined combustion, performance and emissions. The study was carried out both experimentally and statistically. Set as engine parameters, different engine speed, test fuel with isopropanol (IP20-IP40) and excess air ratio for experimental study. Engine speed is $800 \mathrm{rpm}-1200 \mathrm{rpm}$, excess air ratio is 1.6 and 2.8, and isopropanol ratio in test fuel of $20 \%$ and $40 \%$. From the experiment, investigations were made on effective torque, indicated mean effective pressure, indicated thermal efficiency, maximum pressure increase rate, start of combustion (SOC), combustion duration, COVIMEP, HC, CO and NOx. Before the experiments, experimental series were determined with Response Surface Method, Central Compound Design matrix. Experiments were carried out with the experimental series obtained and the data were analysed. Counter charts, ANOVA results and quartic models were obtained by entering the combustion, performance and output of the HCCI engine into the RSM interface. Then, the targeted response parameters were entered and optimization was made to determine the optimum input parameter. Response parameters under optimum operating conditions Effective Torque $11.438 \mathrm{Nm}$, IMEP $4.366 \mathrm{bar}$, MPRR $2.747 \mathrm{bar} /{ }^{\circ} \mathrm{CA}$, COVIMEP $4.364 \%$, CA10 $2.315^{\circ} \mathrm{CA}, \mathrm{CA} 507{ }^{\circ} \mathrm{CA}$, CA10CA90 $36.245^{\circ} \mathrm{CA}$, UHCs $324.562 \mathrm{ppm}$, CO $0.0118 \%$ and NOx $2.549 \mathrm{ppm}$ were determined.

Keywords: HCCI engine, Isopropanol, Response surface method, Design of experiments

\begin{tabular}{lll}
\multicolumn{1}{c}{ History } & Author Contacts & http://dx.doi.org/10.29228/eng.pers.51253 \\
Received: & *Corresponding Author & e-mail addresses : m.safieddin@ @ scu.ac.ir, nacakcagatay @ gazi.edu.tr, thocakulak@ @ mehmetakif.edu.tr. \\
Accepted: & mbabagiray @ aku.edu.tr & Orcid numbers :0000-0002-5164-1284, 0000-0001-6255-1148, 0000-0002-1269-6370, \\
& 0000-0002-2482-6662 & \\
& &
\end{tabular}

\section{Introduction}

Today, an increase is observed in global warming and acid rain events caused by the risk of depletion of fossil fuels and the rapid increase in emission emissions [1-4]. Due to these concerns, researchers have turned to studies aimed at increasing efficiency and reducing harmful emission gases in the energy conversion process. Today, internal combustion engines are widely used for the production of mechanical energy, especially in mobile vehicles. Although compression and spark ignition engines are mostly used in this internal combustion engine group, it is on the agenda for engines operating with the HCCI combustion principle, with high efficiency and low emission gas values [5-8].

The basic operating principle of the HCCI engine can be defined as the start of combustion by taking the fuel / air mixture into the cylinder and compressing it [9-11]. HCCI combustion can occur with liquid or gaseous fuels by making structural changes on the existing internal combustion engine [12]. In addition to combustion, gasoline, diesel fuels, HCCI also allows its use with alternative fuels such as biofuels, biodiesel, and hydrogen [13]. The use of alternative fuels on the HCCI engine enables improvement in parameters such as engine operating efficiency and emission values $[14,15]$.

It is aimed to improve the performance and emission values of the $\mathrm{HCCI}$ engine by adding different additives to the fuels used on HCCI engines [16]. Gainey et al., experimentally studied the input parameters of an HCCI engine and the combustion process by adding different additives to the fuels used. Isopropanol, butanol, ethanol and methanol additives were added to the fuel. They saw that the reactivity of the isopropanol blended fuel is low and the ambient temperature must be high for the combustion to start. With the increase in 
ambient temperature, they achieved the highest NOx emission release with isopropanol additive [17]. Uyumaz et al., experimentally investigated the effect of using isopropanol and n-butanol additive at different concentrations and the inlet air temperature on the HCCI engine. He observed that the start of combustion was delayed in all fuel mixtures with the increase of inlet air temperature. Increasing isopropanol concentration also advanced the initiation of combustion. It concluded that isopropanol fuel burns in a more controlled manner than n-butanol fuel [18]. Calam et al., experimentally investigated the effect of isopropanol use on HCCI engine combustion and emissions. They used pure n-heptane and n-heptane isopropanol fuels as test fuel. They saw that the burning time was prolonged with the use of the fuel added with isopropanol. They also observed a decrease in the rate of pressure increase with the fuel used in isopropanol [19]. Different optimization methods are used to determine optimum engine parameters and fuel mixtures. Ardebili et al. Aimed to determine the optimum fusel oil concentration by using RSM in their studies. They carried out experiments with a total of 5 different fuels between $0 \%$ and $100 \%$. Optimum results were obtained with a fuel mixture with a concentration of $25 \%$ fusel oil [30]. Awad et al. Obtained successful results by using RSM in determining the optimum additive concentration in the fuel mixture. It shows that this method is suitable for use on internal combustion engines [20].

It is known that engine speed and lambda values, which are HCCI engine input parameters, affect engine performance and emissions. It is aimed to keep such parameters at the optimum level for the HCCI engine. The response surface method (RSM) is widely used in the optimization of internal combustion engine parameters. Solmaz et al. used the RSM method for optimization of an HCCI engine parameters. When they compared the values they obtained after optimization with the results they obtained with the experimental method, they obtained successful results [11]. Mahla et al. Optimized using the RSM method in a compression ignition engine operating with biogas and diesel fuel. As a result of the study, it was seen that the parameter values obtained by the optimization method were consistent with the experimental results [21].

In this study, performance, emission, and combustion results of HCCI engine mode under different isopropanol concentrations and engine parameters conditions were obtained experimentally and statistically. Engine speed, excess air ratio and fuel types with different isopropanol concentrations were used as variable parameters. The effective torque, IMEP, ITE, MPRR, COVIMEP, UHCs, CO and NOx values were examined. Statistical analysis was carried out using the RSM in the Design Expert 12 environment. Counter charts, ANOVA results and quartic models were obtained by inputting the performance, emission, and combustion values of the HCCI engine to the RSM interface. Optimization was carried out in order to determine the optimum input parameters by inputting the targeted response parameters from the HCCI engine.

\section{Material and Methods}

\subsection{Experimental Setup}

The experiments were performed in a Ricarda Hydra single cylinder test engine. Besides, in the experiments, SI-HCCI was used as the test engine. Schematic view of the experimental setup and the properties of the test engine are seen in Fig..1. and Table 1, respectively.

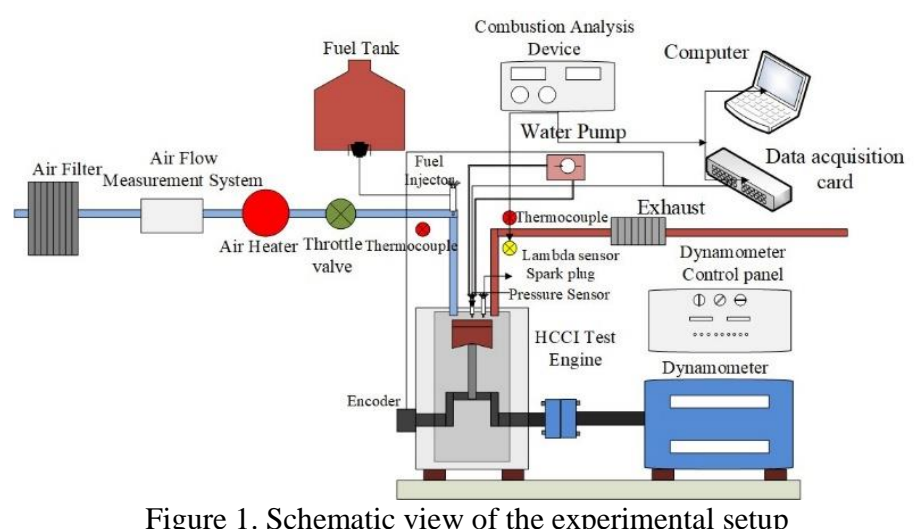

Equations must be numbered consecutively and located at the right margin as in Eq. (1) below. Clear original figures in black and white should be used.

Table 1. Properties of HCCI engine

\begin{tabular}{c|c}
\hline Brand-Model & Ricardo Hydra \\
\hline Number of cylinder & 1 \\
\hline Volume $(\mathrm{mL})$ & 450 \\
\hline Bore x Stroke $(\mathrm{mm})$ & $80.26 \times 88.90$ \\
\hline Compression ratio & $5: 1-13: 1$ \\
\hline Maximum power $(\mathrm{kW})$ & $15 @ 4500 \mathrm{rpm}$ \\
\hline Maximum speed (rpm) & 5400 \\
\hline Maximum cylinder pressure & 120 bar \\
\hline Fuel system & Port type \\
\hline Cooling system & Water cooled \\
\hline
\end{tabular}

During the experiment, a homogeneous air-fuel mixture was taken into the cylinder with the port injection system. The injection amount of the injector was adjusted using the potentiometer. The injectors were electronically controlled to determine fuel consumption and keep the air / fuel ratio constant. Injection properties of all fuels are determined before the tests are carried out. The potentiometer scale was set to 1.0, 2.0, 4.0, 6.0, 8.0 and 10.0 and the test motor was run at constant speed. The gas tank was placed on a precision scale (precision $0.01 \mathrm{~g}$ ) and the fuel quantity was set at 120 seconds. In the current system, the injector is adjusted according to the position of the potentiometer.

In the experiments, the potentiometer was precisely adjusted for each lambda value. The motor was placed in a McClure DC dynamometer capable of absorbing $30 \mathrm{~kW}$ of power. The heating system, which heats the intake air, is in front of the intake manifold attached to the cylinder block. A K type thermocouple was used to measure the air inlet temperature. A closed loop controller was used to keep the temperature constant. In-cylinder pressure was measured with Kistler 6121 model piezoelectric pressure sensor and its technical specifications are given in Table 2 . 
Table 2. Pressure sensor specifications

\begin{tabular}{c|c}
\hline Brand - Model & Kistler -6121 \\
\hline Measuring range (bar) & 0 to 250 \\
\hline Sensivity (pC/bar) & 14.7 \\
\hline Temperature $(\mathrm{K})$ & 223 to 623 \\
\hline Linearity $(+/-\%)$ & $<0.5$ \\
\hline
\end{tabular}

The measured signals were amplified in the Cussons P4110 model combustion analyzer and analyzed using a National Instruments brand USB 6259 model data acquisition card and recorded in the computer. In addition, Opkon brand $0.36 \mathrm{CAD}$ precision encoder was used to determine the position of the piston in the cylinder. The technical characteristics of the encoder are presented in Table 3. Fifty consecutive data cycles were averaged to prevent cyclical differences that could occur during the experiment.

Table 3. Encoder specifications

\begin{tabular}{c|c}
\hline Brand - Model & Opkon \\
\hline Output & Line driver \\
\hline Supply DC Voltage $(\mathrm{V})$ & 5 \\
\hline Shaft - Body Diameter $(\mathrm{mm})$ & $8-50$ \\
\hline Pulse per Rotation & 1000 \\
\hline Temperature $(\mathrm{K})$ & 253 to 353 \\
\hline Max. Operating Speed (rpm) & 4000 \\
\hline
\end{tabular}

The engine was first started in spark ignition mode and then the spark plug was turned off from the control panel to allow HCCI combustion. The engine coolant and lubricating oil temperatures were checked to make the results more stable. As a result of this process, the cooling water temperature was fixed at $343 \mathrm{~K}$ and the lubricating oil temperature as $333 \mathrm{~K}$. The experiments were carried out at an engine speed of 800-1200 rpm and a constant intake air temperature of $333 \mathrm{~K}$. In this study, IP20, IP40 and n-heptane test fuels were used. The properties of $n$-heptane and isopropanol are shown in Table 4 [6, 20, 22, 23].

Table 4. Properties of fusel oil and n-heptane fuels [9]

\begin{tabular}{c|c|c}
\hline & isopropanol & n-heptane \\
\hline RON & 107 & 0 \\
\hline Density $\left(\mathrm{kg} / \mathrm{m} 3\right.$ at $\left.15.4{ }^{\circ} \mathrm{C}\right)$ & 809 & 695 \\
\hline Boiling point $(\mathrm{K})$ & 355 & 371 \\
\hline Low heating value $(\mathrm{kJ} / \mathrm{kg})$ & 30,447 & 44.566 \\
\hline
\end{tabular}

Exhaust gas was analyzed using Bosch's BEA350 emission meter. Table 5 shows the technical characteristics of the exhaust gas analyzer used in the test.

Table 5. Exhaust gas analyser specifications

\begin{tabular}{c|c|c}
\hline & Measuring range & Sensitivity \\
\hline $\mathrm{CO}(\%)$ & $0-14$ & 0.001 \\
\hline $\mathrm{CO} 2(\%)$ & $0-18$ & 0.01 \\
\hline $\mathrm{HC}(\mathrm{ppm})$ & $0-9999$ & 1 \\
\hline $\mathrm{NOx}(\mathrm{ppm})$ & $0-5000$ & 1 \\
\hline $\mathrm{O} 2$ & $0-25$ & 0.01 \\
\hline Opacity $(\%)$ & $0-100$ & 0.1 \\
\hline Lambda & $0-4$ & 0.001 \\
\hline
\end{tabular}

\subsection{Combustion Analysis Method}

The in-cylinder pressure was calculated by averaging the fifty cycle data obtained. For this purpose, a special algorithm was designed using the MATLAB. With the help of this algorithm, in-cylinder pressure, heat release, IMEP, start of combustion, burning time and specified thermal efficiency are calculated.

HRR is determined with the help of the first law of thermodynamics. Therefore, mass and gas leaks in a cycle are ignored. In calculating the heat dissipation, heat transfer from the cylinder wall to the outside is included. HRR based on HCCI engine crankshaft angle is calculated using Eq. (1)of the paper in font 9. They should be numbered consecutively. While referring a journal paper, volume, number, page numbers and year must be given. Standard APA referencing style must be used.

$\frac{d Q}{d \theta}=\frac{k}{k-1} p \frac{d V}{d \theta}+\frac{k}{k-1} V \frac{d P}{d \theta}+\frac{d Q_{\text {heat }}}{d \theta}$

Calculation of the amount of heat transfer occurring on the cylinder walls of the internal combustion engine (ICE) based on Newton's cooling principle is calculated with Eq. (2):

$$
\frac{d Q_{\text {heat }}}{d \theta}=\frac{1}{6 \times n} \times h_{g} \times A \times\left(T_{g}-T_{w}\right)
$$

The ITE value of the HCCI engine was calculated with Eq. (3).

$\eta_{T}=\frac{W_{\text {net }}}{\dot{m}_{\text {fusel oil }} \times Q_{L H V \text { fusel oil }} \dot{m}_{n-\text { heptane }} \times Q_{L H V n-\text { heptane }}}$

The net work value of one cycle of the HCCI engine was calculated with Eq. (4).

$W_{n e t}=\int P d V$

IMEP was calculated with Eq. (5).

$\mathrm{IMEP}=\frac{W_{\text {net }}}{V_{\text {stroke }}}$

\section{Design of Optimization Parameters}

In optimization studies, the results obtained from engine tests are expected to be statistically optimum. Therefore, the response surface methodology (RSM) is used in this research study. The software chosen for the response surface methodology is Design Expert 12. Central Compound Design (CCD) was used in the design of the response surface methodology which is generally preferred in optimizations. The experiments were optimized using ANOVA (analysis of variance) table. Engine speed (rpm), air excess coefficient and 
fuel type were determined as independent variables. The design matrix has been changed for the three variables and the limit parameters are given in the Table 6 . Total of 26 experiments were expected for three determined dependent variables in order to provide optimum working conditions.

Table 6. Operating range and levels for independent variables

\begin{tabular}{c|c|c|c|c|c|c|c}
\hline \multirow{2}{*}{$\begin{array}{c}\text { Ind. varia } \\
\text { bles }\end{array}$} & \multirow{2}{*}{$\begin{array}{c}\text { Uni } \\
\mathbf{t}\end{array}$} & $\mathbf{X}_{\mathbf{i}}$ & \multicolumn{5}{|c}{ Operating Range and Levels } \\
\cline { 4 - 8 } & & $-\boldsymbol{\alpha}$ & $\mathbf{- 1}$ & $\mathbf{0}$ & $\mathbf{+ 1}$ & $+\boldsymbol{\alpha}$ \\
\hline $\begin{array}{c}\text { Engine spe } \\
\text { ed }\end{array}$ & $\begin{array}{c}(\mathrm{rp} \\
\mathrm{m})\end{array}$ & $\mathrm{X}_{1}$ & 800 & 800 & $\begin{array}{c}10 \\
00\end{array}$ & 1200 & $\begin{array}{c}120 \\
0\end{array}$ \\
\hline Lambda & & $\mathrm{X}_{2}$ & 1,6 & 1,6 & $\begin{array}{c}2, \\
2\end{array}$ & 2,8 & 2,8 \\
\hline $\begin{array}{c}\text { Isopropano } \\
\text { 1 ratio }\end{array}$ & $(\%)$ & $\mathrm{X}_{3}$ & 20 & 20 & - & 40 & 40 \\
\hline
\end{tabular}

In the establised model, the engine speed was determined between $800-1200 \mathrm{rpm}$, and the air excess coefficient was determined between 1.6 - 2.8. IP20 (20\% Isopropanol-80\% Heptane) and IP40 (40\% Isopropanol-60\% Heptane) were selected as the fuel type. Effective torque (Nm), IMEP (bar), MPRR (bar/oCA), COVIMEP (\%), CA10 $\left({ }^{\circ}\right), \mathrm{CA} 50\left(^{\circ}\right), \mathrm{CA} 10-\mathrm{CA} 90\left(^{\circ}\right)$, indicated thermal efficiency $(\%)$ and $\mathrm{CO}(\%), \mathrm{HC}(\mathrm{ppm})$, and NOx (ppm) emissions were determined as dependent variables (response variables). The quartic model was chosen for the optimization of all dependent variables. General equation of the quartic model [24]:

$$
\eta=\beta_{0}+\sum_{i=1}^{k} \beta_{i} x_{i}+\sum_{i=1}^{k} \beta_{i i} x_{i}^{2}+\sum_{i=1}^{k} \beta_{i i i} x_{i}^{3}+\sum_{i=1}^{k} \beta_{i i i i} x_{i}^{4}+\sum_{i=1}^{k} \sum_{j=1, i<j}^{k} \beta_{i j} x_{i} x_{j}
$$

In Eq. (6), $\eta$ is the response, $\beta_{0}$ means constant, $\beta_{i}, \beta_{i i}$, $\beta_{i i i}$ and $\beta_{i i i i}$ are regression coefficients, $\beta_{i j}$ means quartic coefficient, and $x_{i}$ denotes input variable. The significance level F-value and $\mathrm{p}$-value of the independent variables are determined. In dependent variables, the fact that the large F-value and small p-value are increases the importance level. The p-value shows the effect of input parameters on response values. If the p-value of any input parameter is less than 0.05 , that parameter has a great effect on the model [25]. The indicator that the regression statistics are compatible is expressed with goodness of fit $\left(\mathrm{R}^{2}\right)$. The $\mathrm{R}^{2}$ value indicates the agreement of the statistical model results with the experimental results [26].

\section{Analysis of the Model}

The model which to coherent the between parameters are fine because the difference between R2 and the goodness of predictions (Adj. R2) of the regression statistics in all the analysis results are less than 0.02. Emission and performance values have been examined and optimized by taking into account parameters such as engine speed, air excess coefficient and different fuel type, which we have determined as input values in the HCCI engine that we conducted the experiments. The values obtained were analysed and interpreted in detail under separate titles and detailed graphics. In ad- dition, optimum parameter values were determined to reach the targeted response values.

\subsection{Interaction Effects of Optimization}

\subsubsection{Effective torque}

The optimization values about effective torque are shown in the Table 7. According to the ANOVA results for effective torque, it is seen that the established model has a significant effect on effective torque. The p-value that measures the effect of engine speed, air excess coefficient and fuel type on effective torque is below 0.05. According to the F-value, it can be concluded that the fuel type is more effective on the effective torque than the engine speed and the air excess coefficient.

Table 7. ANOVA table for effective torque (Nm)

\begin{tabular}{c|c|c|c|c|l}
\hline Source & $\begin{array}{c}\text { Sum of } \\
\text { Sq. }\end{array}$ & $\begin{array}{c}\text { Mean S } \\
\text { q. }\end{array}$ & F-value & p-value & Remarks \\
\hline Model & 123,38 & 7,71 & 136,89 & $<0.0001$ & significant \\
\hline $\begin{array}{c}\mathrm{X}_{1} \text { - Engi } \\
\text { ne speed }\end{array}$ & 0,6006 & 0,6006 & 10,66 & 0,0098 & significant \\
\hline $\begin{array}{c}\mathrm{X}_{2} \text {-Lam } \\
\text { bda }\end{array}$ & 11,39 & 11,39 & 202,22 & $<0.0001$ & significant \\
\hline $\mathrm{X}_{3}$-Fuel & 29,09 & 29,09 & 516,46 & $<0.0001$ & significant \\
\hline Residual & 0,507 & 0,0563 & & & \\
\hline Cor Total & 123,88 & & & & \\
\hline
\end{tabular}

In the analysis which is using the quartic model, the R2 value of the goodness of fit is checked to determine the correlation fit of the input parameters used in the research. For the effective torque, the $\mathrm{R} 2$ value was seen as 0.9959 and the regulated R2 (Adj. R2) value was obtained as 0.9886 . Since the difference is less than 0.02 , it has been seen that the results are within acceptable limits and compatible. The quartic model Eq. (7) for effective torque generated by the response surface method.

$$
\begin{aligned}
T_{e f}(\mathrm{Nm}) & =6-0,388 X_{1}-1,688 X_{2}+1,584 X_{3} \\
& -0,431 X_{1} X_{2}-0,113 X_{2} X_{3}+1,638 X_{1}^{2} \\
& +0,888 X_{2}^{2}-0,394 X_{1} X_{2} X_{3}+0,569 X_{1}^{2} X_{2} \\
& -0,155 X_{1}^{2} X_{3}+0,606 X_{1} X_{2}^{2}+0,52 X_{2}^{2} X_{3} \\
& -1,394 X_{1}^{2} X_{2}^{2}-0,344 X_{1}^{2} X_{2} X_{3}+0,894 X_{1} X_{2}^{2} X_{3}
\end{aligned}
$$

The effective torque value in internal combustion engines is important parameters in terms of performance. Figures $2 \mathrm{a}$ and $2 \mathrm{~b}$ there are graphs of IP20 and IP40 fuels, respectively. The graphs show the effect of air excess coefficient on effective torque depending on engine speed. The increase in the amount of isopropanol in the fuel mixture has increased the effective torque value. Isopropanol's highoctane number and its density in the mixture is the reason for the increase. In addition, as the excess air coefficient increases in the experiments, the torque value decreases. Reason for this is that the air / fuel ratio in the cylinder is a lean mixture. While a maximum torque of $6.5 \mathrm{Nm}$ was obtained in the experiments with IP20, maximum torque values of $12.4 \mathrm{Nm}$ were reached with IP40 [9, 27]. 


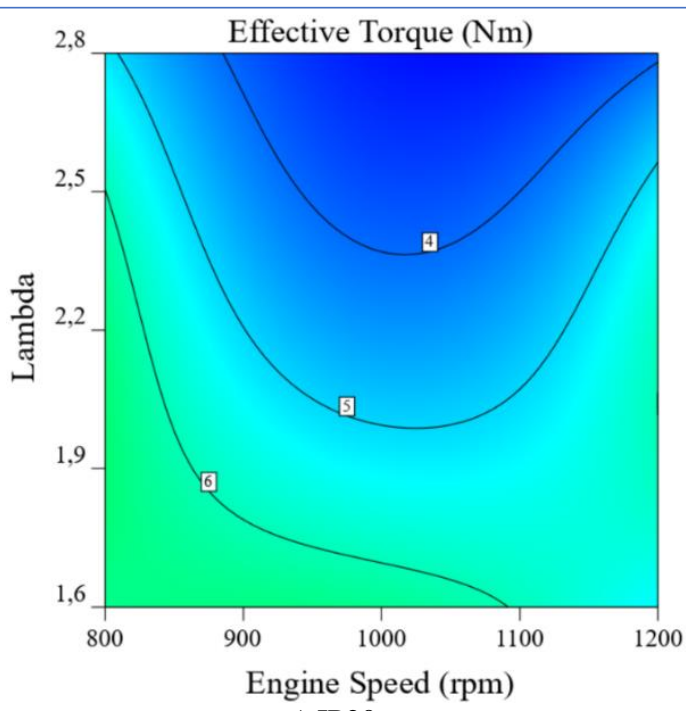

a) IP20

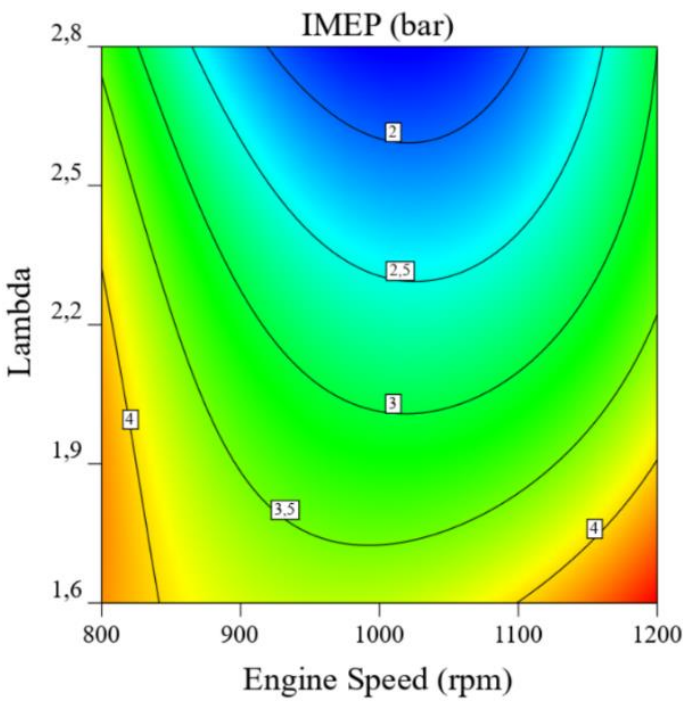

b) IP40

Figure 2. Effect of lambda and engine speed on effective torque(a and b)

\subsubsection{Indicated mean effective pressure (IMEP)}

ANOVA results with IMEP values are shown in Table 8. As seen in the table, it is significant in terms of the IMEP of the model. It is seen that the effect of independent variables on IMEP is significant ( $\mathrm{p}$-value $<0.05$ ). The $\mathrm{p}$-value is less than 0.05 in all input parameters. The $\mathrm{p}$-value is $<0.0001$ in all parameters of engine speed, air excess coefficient and fuel type. The fuel type has the highest $F$ value than others. This means that the fuel is an effective parameter on IMEP.

Table 8. ANOVA table for indicated mean effective pressure (IMEP)

\begin{tabular}{c|c|c|c|c|c}
\hline Source & $\begin{array}{c}\text { Sum of } \\
\text { Sq. }\end{array}$ & $\begin{array}{c}\text { Mean S } \\
\text { q. }\end{array}$ & F-value & p-value & Remarks \\
\hline Model & 10,7 & 0,669 & 798,9 & $<0.0001$ & $\begin{array}{c}\text { significan } \\
\mathrm{t}\end{array}$ \\
\hline $\begin{array}{c}\mathrm{X}_{1-} \text { Engi } \\
\text { ne speed }\end{array}$ & 0,1846 & 0,1846 & 220,43 & $<0.0001$ & $\begin{array}{c}\text { significan } \\
\mathrm{t}\end{array}$ \\
\hline $\begin{array}{c}\mathrm{X}_{2} \text {-Lam } \\
\text { bda }\end{array}$ & 1,59 & 1,59 & 1897,57 & $<0.0001$ & $\begin{array}{c}\text { significan } \\
\mathrm{t}\end{array}$ \\
\hline $\mathrm{X}_{3}$-Fuel & 3,72 & 3,72 & 4438,59 & $<0.0001$ & $\begin{array}{c}\text { significan } \\
\mathrm{t}\end{array}$ \\
\hline Residual & 0,0075 & 0,0008 & & & \\
\hline Cor Total & 10,71 & & & & \\
\hline
\end{tabular}

For the indicated mean effective pressure (IMEP), the correlation coefficient R2 was 0.9990 and the adjusted correlation coefficient R2 (Adj. R2) was 0.9980. Since the difference is less than 0.02, it has been seen that the results are within acceptable limits and compatible. The quartic model Eq. (8) generated by the response surface method for indicated mean effective pressure.

$$
\begin{aligned}
& \operatorname{IMEP}(\text { bar })=3,245-0,215 X_{1}-0,63 X_{2}-0,566 X_{3}-0,13 X_{1} X_{2} \\
& -0,068 x_{1} x_{3}-0,395 x_{2} x_{3}+0,676 x_{1}^{2}-0,216 x_{2}^{2} \\
& -0,077 x_{1} x_{2} x_{3}+0,229 x_{1}^{2} x_{2}+0,458 x_{1}^{2}+0,128 x_{1} x_{2}^{2} \\
& +0,231 X_{2}^{2} X_{3}+0,177 X_{1}^{2} x_{2} X_{3}+0,161 X_{1} X_{2}^{2} X_{3}
\end{aligned}
$$
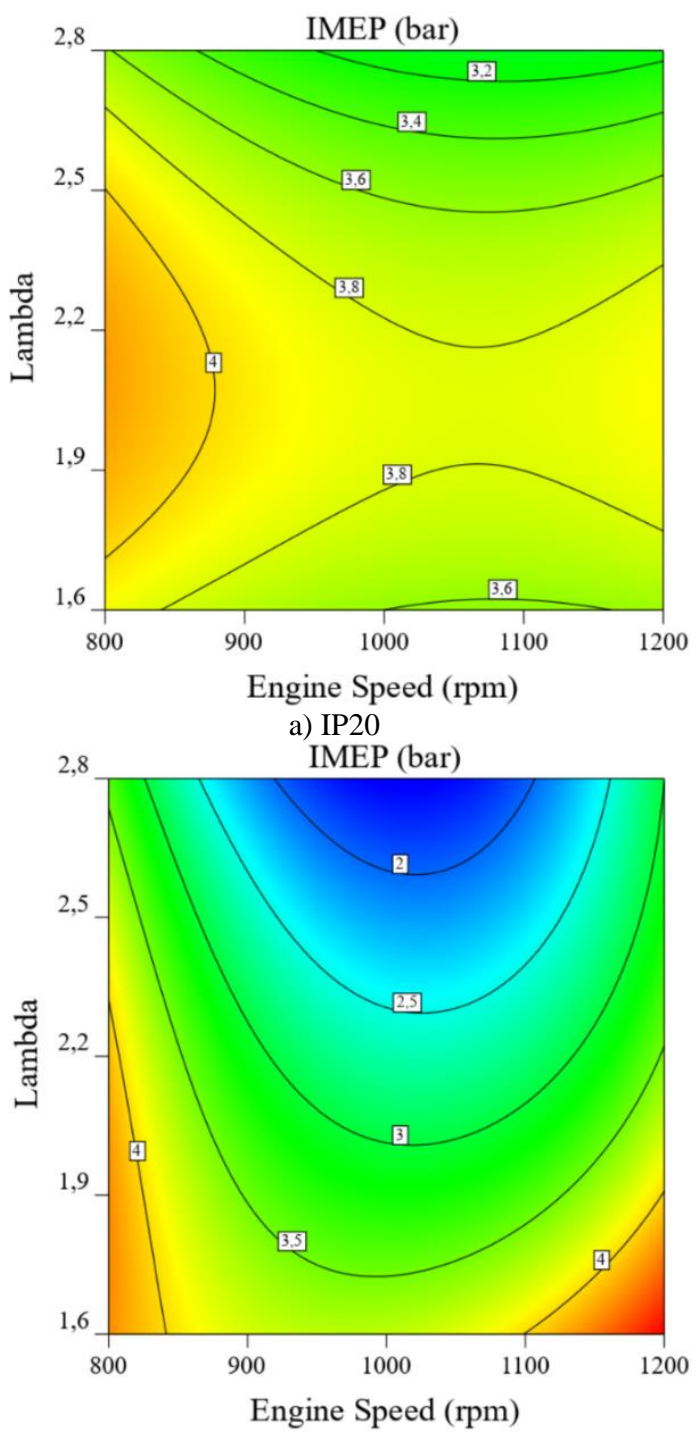

b) IP40

Figure 3. Effect of lambda and engine speed on indicated mean effective pressure (IMEP) ( $a$ and $b$ )

Figures $3 \mathrm{a}$ and $3 \mathrm{~b}$ shows the effect of the air excess coefficient and engine speed on IMEP of the HCCI engine operating with IP20 and IP40 fuels, respectively. In both fuel types, the IMEP air excess coefficient was 1.6 and the lowest IMEP coefficient was obtained under 2.8. The engine could not be started in conditions where the air excess coefficient is lower than 1.6. The reason for this is that the 
engine knocks due to the rich mixture of the fuel taken into the cylinder [28]. The conditions with an excess air coefficient of 1.6 to 2.8 indicate the operating range in HCCI engines for n-heptane isopropanol mixture fuel. At values where the excess air coefficient is higher than 2.8, the combustion in the HCCI engine could not be fully achieved because the engine did not work properly. Combustion slows down as the octane number of the fuel obtained by mixing isopropanol with n-heptane fuel increases [18, 29].

\subsubsection{Maximum pressure rise rate (MPRR)}

ANOVA results for maximum pressure rise rate (MPRR) is showed the statistical values of this study are shown in Table 9. According to the ANOVA results, it is seen that the model is significant and important in terms of MPRR. The p-value measuring the effect of the model formed by the air excess coefficient and fuel type on the maximum pressure increase rate is below 0.05 . However, the pvalue of the engine speed is above 0.05 . So the engine speed has a non-significant effect on the MPRR. These values also show that the change of the maximum pressure increase rate does not depend on the engine speed. When the ANOVA analysis is examined, the air excess coefficient has the highest F-value among the other two input parameters. In this case, it is seen that the air excess coefficient is effective on the MPRR.

Table 9. ANOVA table for maximum pressure rise rate (MPRR)

$$
\text { (bar } \left./{ }^{\circ} \mathrm{CA}\right)
$$

\begin{tabular}{c|c|c|c|c|c}
\hline Source & $\begin{array}{c}\text { Sum of } \\
\text { Sq. }\end{array}$ & $\begin{array}{c}\text { Mean S } \\
\text { q. }\end{array}$ & F-value & p-value & Remarks \\
\hline Model & 439,02 & 27,44 & 79,25 & $<0.0001$ & $\begin{array}{c}\text { significan } \\
\mathrm{t}\end{array}$ \\
\hline $\begin{array}{c}\mathrm{X}_{1} \text { - Engi } \\
\text { ne speed }\end{array}$ & 0,9487 & 0,9487 & 2,74 & 0,1322 & $\begin{array}{c}\text { not signif } \\
\text { icant }\end{array}$ \\
\hline $\begin{array}{c}\mathrm{X}_{2} \text {-Lam } \\
\text { bda }\end{array}$ & 89,7 & 89,7 & 259,08 & $<0.0001$ & $\begin{array}{c}\text { significan } \\
\mathrm{t}\end{array}$ \\
\hline $\mathrm{X}_{3}$-Fuel & 7,46 & 7,46 & 21,55 & 0,0012 & $\begin{array}{c}\text { significan } \\
\mathrm{t}\end{array}$ \\
\hline Residual & 3,12 & 0,3462 & & & \\
\hline Cor Total & 442,14 & & & & \\
\hline
\end{tabular}

About the maximum pressure rise rate (MPRR), the correlation coefficient R2 was 0.9930 and the adjusted correlation coefficient R2 (Adj. R2) was 0.9804. It was seen that the correlation values were within acceptable boundary conditions. The quartic model Eq. (9) for maximum pressure rise rate generated by the response surface method.

$$
\begin{aligned}
\operatorname{MPRR}(\mathrm{bar} / \mathrm{CA}) & =2,04-4,736 X_{2}-0,802 X_{3}+0,86 X_{1} X_{2} \\
+ & 1,337 X_{1}^{2}+3,726 X_{2}^{2}+0,606 X_{1} X_{2} X_{3} \\
& -1,378 X_{1}^{2} X_{3}-1,238 X_{1}^{2} X_{2}^{2}+1,974 X_{1}^{2} X_{2} X_{3}
\end{aligned}
$$

Figures $4 \mathrm{a}$ and $4 \mathrm{~b}$ show the effect of IP20 and IP40 fuels on maximum pressure rise rate, respectively. A decrease was observed in MPRR values with the increase of excess air in both fuels. Reason for this is that the amount of fuel taken into the cylinder is reduced due to the lean mixture caused by the excess air. In addition, the MPRR value of IP40 fuel is lower than IP20. This is because high octane fuel slows down the combustion $[19,29,30]$. In the experiments conducted with IP40 fuel, the lowest maximum pressure rate was measured as $0.84 \mathrm{bar} /{ }^{\circ} \mathrm{CA}$ at 2.8 air excess coefficient at 1200 $\mathrm{rpm}$. Under the same conditions, the maximum pressure rise rate of IP20 fuel was found to be $1.34 \mathrm{bar} /{ }^{\circ} \mathrm{CA}$, which is the lowest MPRR value among the measured values in IP20 fuel. Although the low MPRR value is aimed for internal combustion engines, it is seen that it is at an acceptable level up to $10 \mathrm{bar} /{ }^{\circ} \mathrm{CA}[31]$.

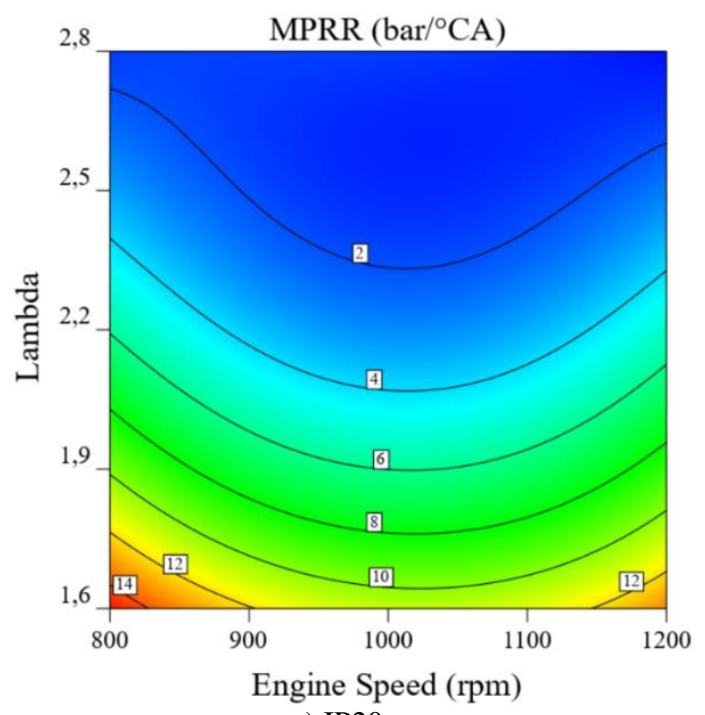

a) IP20



b) IP40

Figure.4. Effect of lambda and engine speed on maximum pressure rise rate (MPRR) ( $a$ and $b$ )

\subsection{4. $\mathrm{COV}_{\text {IMEP }}$}

ANOVA results with COVIMEP values are given in Table 10. As seen in the ANOVA table, the effect of engine speed, air excess coefficient and fuel type on COVIMEP is significant. When the table was examined, it was seen that the model was meaningful. The pvalue of the model and all input parameters is less than 0.0001. When the ANOVA table is examined according to the F-value, it is seen that the air excess coefficient is more important on COVIMEP than the others. 
Table 10. ANOVA table for COVIMEP (\%)

\begin{tabular}{c|c|c|c|c|c}
\hline Source & $\begin{array}{c}\text { Sum of } \\
\text { Sq. }\end{array}$ & $\begin{array}{c}\text { Mean } \\
\text { Sq. }\end{array}$ & F-value & p-value & Remarks \\
\hline Model & 64,58 & 4,04 & 484,94 & $<0.0001$ & significant \\
\hline $\begin{array}{c}\mathrm{X}_{1} \text { - Engi } \\
\text { ne speed }\end{array}$ & 3,79 & 3,79 & 455,73 & $<0.0001$ & significant \\
\hline $\begin{array}{c}\mathrm{X}_{2} \text {-Lam } \\
\text { bda }\end{array}$ & 13,08 & 13,08 & 1571,91 & $<0.0001$ & significant \\
\hline $\mathrm{X}_{3}$-Fuel & 11,19 & 11,19 & 1344,77 & $<0.0001$ & significant \\
\hline Residual & 0,0749 & 0,0083 & & & \\
\hline Cor Total & 64,65 & & & & \\
\hline
\end{tabular}

The coefficient R2 of the model created for COVIMEP was 0.9988 and the adjusted correlation coefficient R2 (Adj. R2) value was 0.9968 . These results show that the created model is congruent. The quartic model Eq. (10) generated by the response surface method for $\mathrm{COV}_{\mathrm{IMEP}}$ :

$$
\begin{aligned}
\operatorname{COV}_{\text {IMEP }}(\%) & =3,987+0,974 X_{1}+1,809 X_{2}+0,982 X_{3} \\
& +0,341 X_{1} X_{2}+0,874 X_{1} X_{3}+0,524 X_{2} X_{3} \\
& -0,971 X_{1}^{2}+0,348 X_{2}^{2}-1,228 X_{1}^{2} X_{2}+0,163 X_{1}^{2} X_{3} \\
& -0,658 X_{1} X_{2}^{2}-0,745 X_{2}^{2} X_{3}+1,623 X_{1}^{2} X_{2}^{2} \\
& +0,641 X_{1}^{2} X_{2} X_{3}-0,563 X_{1} X_{2}^{2} X_{3}
\end{aligned}
$$

Figures 5a and 5b show COVIMEP values of IP20 and IP40 fuels, respectively. The charts are based on the excess air rate and engine speed. An increase in COVIMEP values was observed with the increase of excess air in the use of both types of fuels. This increase causes an increase in the probability of engine knock. In addition, the increase in the amount of isopropanol in the fuel caused an increase in the COVIMEP value. The reason for this is that the octane number slows down the combustion and causes the combustion process to be delayed. Also, the latent heat of vaporization of isopropanol is higher than $n$-heptane, causing an additional delay of combustion $[19,32]$. Under these conditions where the engine speed is 1200 rpm and the excess air ratio is 2.8, approximately $8 \%$ COVIMEP value was obtained with IP40 fuel and approximately $4.40 \%$ with IP20 fuel. The maximum value of COVIMEP should not exceed the $10 \%$ threshold [33].

\subsubsection{CA10}

ANOVA results with CA10 values are given in Table 11. As seen in the ANOVA table, the p-value of the input parameters is less than 0.05 . This shows that the effect of engine speed, air excess coefficient and fuel type for CA10 value is significantly important. The pvalue of the created model is less than 0.0001 . Considering the Fvalue, it is seen that the input parameters with a high effect are excess air ratio, fuel and engine speed, respectively.

The correlation coefficient (R2) of the model created for CA10 $\left(^{\circ}\right)$ was 0,9994 and the adjusted correlation coefficient R2 (Adj. R2) value was 0,9984 . These results show that the created model is congruent. The quartic model Eq. (11) for CA10 $\left(^{\circ}\right)$ generated by the response surface method.
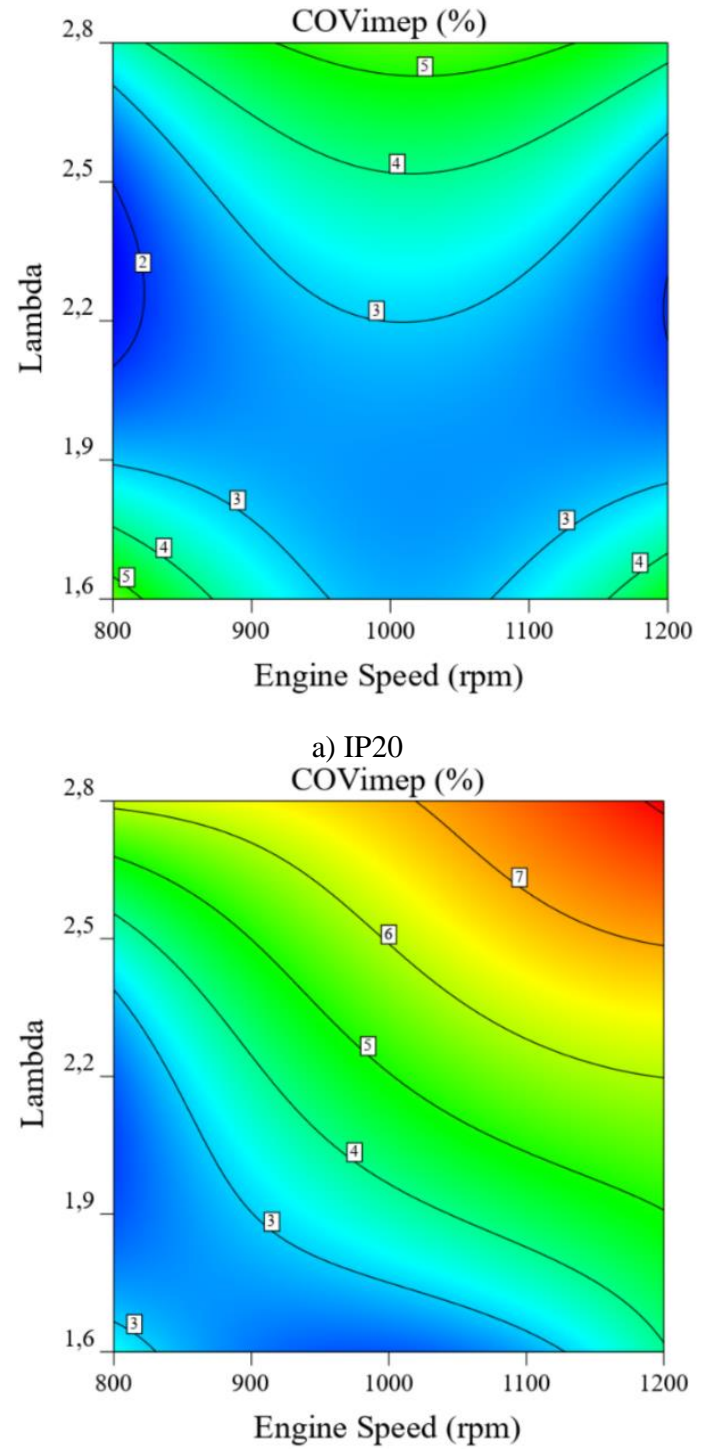

b) IP40

Figure 5. Effect of lambda and engine speed on $\operatorname{COV}_{\operatorname{IMEP}}(\mathrm{a}$ and $\mathrm{b})$

$$
\begin{aligned}
& \mathrm{CA} 10\left(^{\circ}\right)=2,88-0,27 X_{1}+2,82 X_{2}+1,407 X_{3}-0,63 X_{1} X_{2} \\
& -0,45 X_{1} X_{3}+0,96 X_{2} X_{3}+0,27 X_{1}^{2}-1,56 X_{2}^{2} \\
& -0,18 X_{1} X_{2} X_{3}-0,66 X_{1}^{2} X_{2}+0,206 X_{1}^{2} X_{3} \\
& +0,54 X_{1} X_{2}^{2}-0,304 X_{2}^{2} X_{3}+0,57 X_{1}^{2} X_{2}^{2} \\
& -0,51 X_{1}^{2} X_{2} X_{3}+0,27 X_{1} X_{2}^{2} X_{3}
\end{aligned}
$$

Figures $6 \mathrm{a}$ and $6 \mathrm{~b}$ shows the start of combustion (SOC) in HCCI engine with use of IP20 and IP40 test fuels, respectively. The graphs are based on the excess air rate and engine speed. In internal combustion engines, the crank angle position corresponding to different percentages of heat dissipation in the cylinder (10\%, 50\% and 90\%) are expressed as CA10, CA50 and CA90, respectively. The crank angle position (CA10) corresponding to a heat dissipation of $10 \%$ is considered to be the SOC. The start of combustion in HCCI combustion depends on the chemical kinetics and the pressure-temperature history in the combustion chamber [34]. shows. For this reason, the combustion starts at earlier crank angles. It is seen that the start of the combustion is delayed for all test fuels with the depletion of 
the mixture, ie the increase in the excess air coefficient. The main reason for this is the low reactivity of the mixture at high air excess coefficient values [28] (lambda 2.2 and engine speed $1000 \mathrm{rpm}$ ). IP20 fuel starts combustion $1.44^{\circ} \mathrm{CA}$ after TDC, and IP40 fuel starts to burn only $4.32^{\circ} \mathrm{CA}$ after TDC.

Table 11. ANOVA table for CA10 $\left(^{\circ}\right)$

\begin{tabular}{c|c|c|c|c|c}
\hline Source & $\begin{array}{c}\text { Sum of } \\
\text { Sq. }\end{array}$ & $\begin{array}{c}\text { Mean S } \\
\mathbf{q} \cdot\end{array}$ & F-value & p-value & Remarks \\
\hline Model & 138,17 & 8,64 & 978,24 & $<0.0001$ & $\begin{array}{c}\text { significan } \\
t\end{array}$ \\
\hline $\begin{array}{c}\mathrm{X}_{1} \text { - Engi } \\
\text { ne speed }\end{array}$ & 0,2916 & 0,2916 & 33,03 & 0,0003 & $\begin{array}{c}\text { significan } \\
\mathrm{t}\end{array}$ \\
\hline $\begin{array}{c}\mathrm{X}_{2} \text {-Lam } \\
\text { bda }\end{array}$ & 31,81 & 31,81 & 3603,43 & $<0.0001$ & $\begin{array}{c}\text { significan } \\
\mathrm{t}\end{array}$ \\
\hline $\mathrm{X}_{3}$-Fuel & 22,96 & 22,96 & 2601 & $<0.0001$ & $\begin{array}{c}\text { significan } \\
\mathrm{t}\end{array}$ \\
\hline Residual & 0,0794 & 0,0088 & & & \\
\hline $\begin{array}{c}\text { Cor Tota } \\
1\end{array}$ & 138,25 & & & & \\
\hline
\end{tabular}
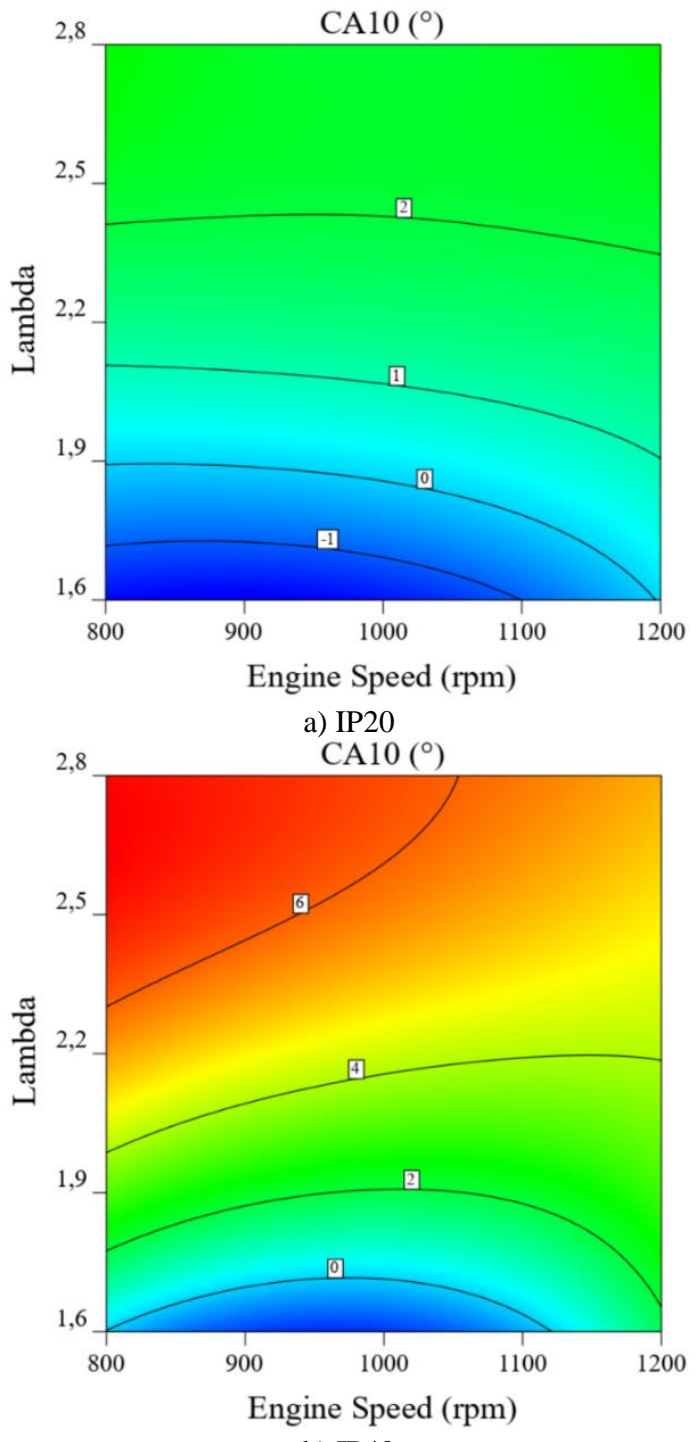

b) IP40

Figure 6. Effect of lambda and engine speed on CA10(a and b)

\subsubsection{CA50}

ANOVA results with CA50 values are given in Table 12. As seen in the ANOVA table, the effect of the engine speed ( $\mathrm{p}$-value = 0.0714) is not significant, while the effect of the air excess coefficient and fuel type on the model, whose p-value is less than 0.05 which is significant. However, the generally created model is meaningful. The p-value of the created model is less than 0.0001. Considering the F-value, it is seen that the fuel type is more effective than other input parameters.

Table 12. ANOVA table for CA50 ( $\left.{ }^{\circ}\right)$

\begin{tabular}{c|c|c|c|c|c}
\hline Source & $\begin{array}{c}\text { Sum of } \\
\text { Sq. }\end{array}$ & $\begin{array}{c}\text { Mean S } \\
\text { q. }\end{array}$ & F-value & p-value & Remarks \\
\hline Model & 437,39 & 27,34 & 55,05 & $<0.0001$ & $\begin{array}{c}\text { significan } \\
t\end{array}$ \\
\hline $\begin{array}{c}\mathrm{X}_{1}-\text { Engi } \\
\text { ne speed }\end{array}$ & 2,07 & 2,07 & 4,18 & 0,0714 & $\begin{array}{c}\text { not signif } \\
\text { icant }\end{array}$ \\
\hline $\begin{array}{c}\mathrm{X}_{2} \text {-Lam } \\
\text { bda }\end{array}$ & 49,28 & 49,28 & 99,25 & $<0.0001$ & $\begin{array}{c}\text { significan } \\
\mathrm{t}\end{array}$ \\
\hline $\mathrm{X}_{3}$-Fuel & 175,69 & 175,69 & 353,82 & $<0.0001$ & $\begin{array}{c}\text { significan } \\
\mathrm{t}\end{array}$ \\
\hline Residual & 4,47 & 0,4966 & & & \\
\hline $\begin{array}{c}\text { Cor Tota } \\
1\end{array}$ & 441,86 & & & & \\
\hline
\end{tabular}

The correlation coefficient (R2) of the model created for CA50 $\left(^{\circ}\right)$ was 0.9899 and the adjusted correlation coefficient R2 (Adj. R2) value was 0.9719 . These results show that the created model is congruent. The quartic model Eq. 12 for CA50 $\left(^{\circ}\right)$ by the response surface method.

$\operatorname{CA} 50\left(^{\circ}\right)=8,46+3,51 X_{2}+3,89172 X_{3}-1,62 X_{1} X_{3}-1,53 X_{2}^{2}$

Figures $7 \mathrm{a}$ and $7 \mathrm{~b}$ show the crank angle CA50 values at which $50 \%$ of the cumulative heat dissipation occurs for HCCI combustion in the use of IP20 and IP40 test fuels, respectively, and the location of the CA50 significantly affects the thermal efficiency. The octane number is increasing and the fuel is more difficult to evaporate. With the increase in the amount of isopropanol in the fuel mixture, the combustion degree is delayed. The situation that causes this is, as the mixture becomes leaner, the reaction rate decreases and the combustion slows down. Accordingly, the CA50 is delayed $[35,36]$. CA50 value, which represents the crankshaft angle at which $50 \%$ of the combustion occurs, should occur when the piston exceeds TDC by 7-11 ${ }^{\circ} \mathrm{CA}$ [37]. It is seen that the CA50 values are lower in the use of IP20 fuel mixture compared to the use of the IP40 fuel mixture, because the resistance to combustion increases with the increase of isopropanol concentration in the fuel. 


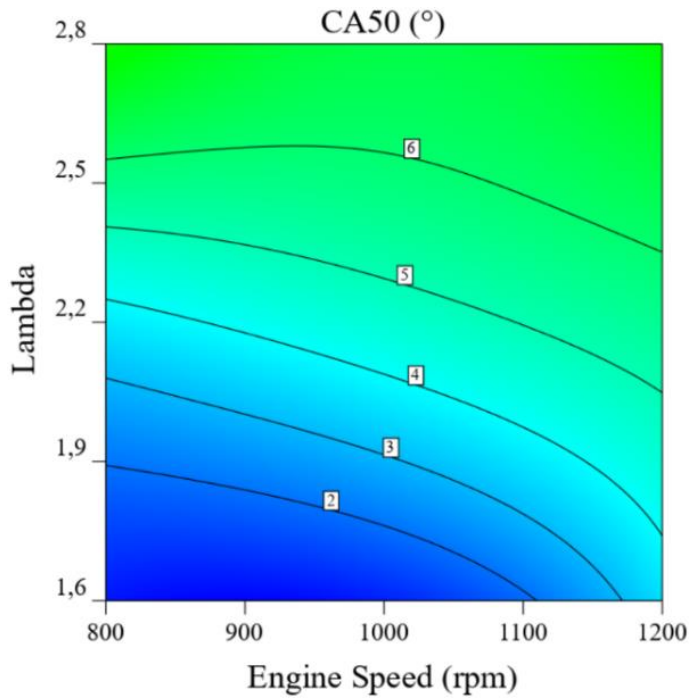

a) IP20

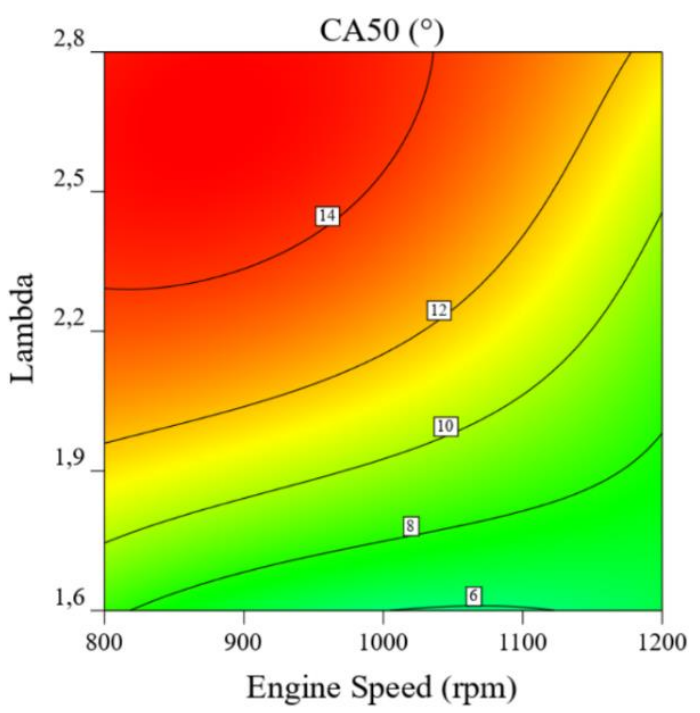

b) IP40

Figure 7. Effect of lambda and engine speed on CA50(a and b)

\subsubsection{CA10-CA90}

ANOVA results with CA10-CA90 values are given in Table 13. As seen in the ANOVA table, the p-value of all input parameters is less than 0.05 . Generally, the created model is meaningful. The pvalue of the created model is less than 0.0001 . Considering the Fvalue, it is seen that the excess air coefficient is more effective than the other input parameters.

The correlation coefficient (R2) of the model created for CA10CA90 $\left(^{\circ}\right)$ was 0.9919 and the adjusted correlation coefficient R2 (Adj. R2) value was 0.9776. Since the difference between them is less than 0.02, it shows that the created model is compatible. The quartic model Eq.13 for CA10-CA90 $\left(^{\circ}\right)$ generated by the response surface method.

$$
\begin{aligned}
\text { CA10-CA90 } & \left({ }^{\circ}\right)=38,88-0,81 X_{1}+2,7 X_{2}+0,962069 X_{3} \\
& +0,54 X_{2} X_{3}-0,81 X_{1}^{2}-1,44 X_{2}^{2}+0,675 X_{1} X_{2}^{2}(13) \\
& +1,125 X_{1}^{2} X_{2}^{2}-0,585 X_{1}^{2} X_{2} X_{3}
\end{aligned}
$$

Table 13. ANOVA table for CA10-CA90 $\left(^{\circ}\right)$

\begin{tabular}{c|c|c|c|c|c}
\hline Source & $\begin{array}{c}\text { Sum of S } \\
\text { q. }\end{array}$ & Mean Sq. & F-value & p-value & Remarks \\
\hline Model & 124,17 & 7,76 & 69,27 & $<0.0001$ & significant \\
\hline $\begin{array}{c}\mathrm{X}_{1}-\text { Engin } \\
\text { e speed }\end{array}$ & 2,62 & 2,62 & 23,42 & 0,0009 & significant \\
\hline $\begin{array}{c}\mathrm{X}_{2} \text {-Lamb } \\
\text { da }\end{array}$ & 29,16 & 29,16 & 260,28 & $<0.0001$ & significant \\
\hline $\mathrm{X}_{3}$-Fuel & 10,74 & 10,74 & 95,83 & $<0.0001$ & significant \\
\hline Residual & 1,01 & 0,112 & & & \\
\hline Cor Total & 125,17 & & & & \\
\hline
\end{tabular}

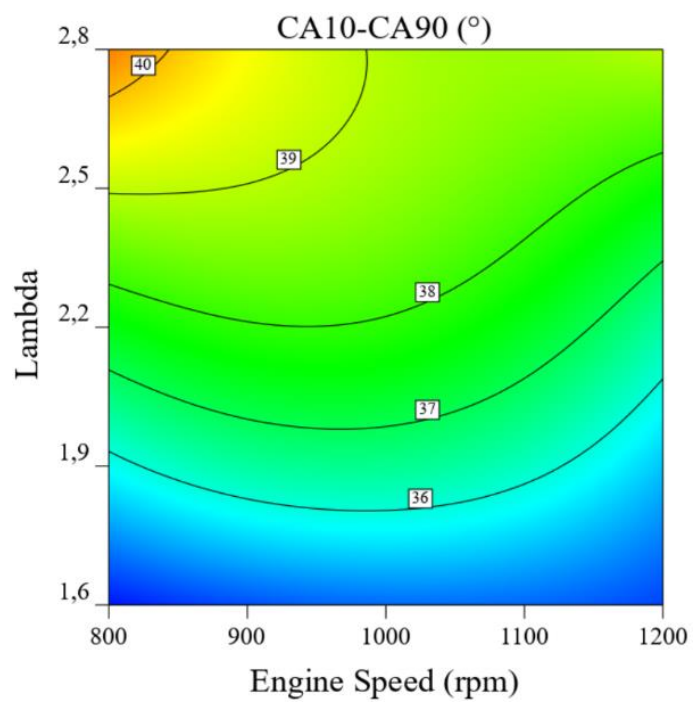

a) IP20

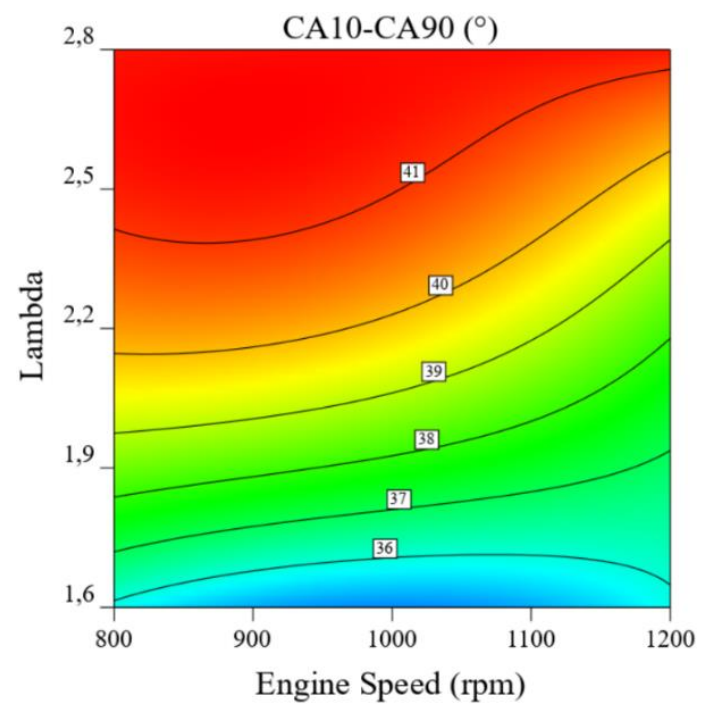

b) IP40

Figure 8. Effect of lambda and engine speed on CA10-90(a and b)

Combustion duration (CD) is named as CA10-CA90 in combustion analysis. Figures $8 \mathrm{a}$ and $8 \mathrm{~b}$ show the combustion durations of the IP20 and IP40 test fuels, respectively, CA10 indicates the point 
where $10 \%$ of the cumulative heat release emerges (also the beginning of the combustion), while CA90 indicates the point where $90 \%$ of the cumulative heat release emerges in combustion analysis and the combustion is finished. It is considered as the moment [6]. CA10-CA90 expresses the combustion duration as the crank angle. As the fuel rich mixture taken into the cylinder, the combustion duration has decreased. Therefore, the combustion duration was shorter in the tests with low excess air coefficient. In addition, the increase in the octane number of the fuel increased the combustion duration. Increasing the octane number delays low and high temperature oxidation zones in HCCI combustion and causes the negative temperature zone to expand [38]. Therefore, the combustion duration of IP40 fuels took longer than IP20 fuels. In the experiment performed with 2.8 air excess coefficient and $800 \mathrm{rpm}$ using IP40 fuel, the highest combustion duration $\left(41.4^{\circ} \mathrm{CA}\right)$ was realized, while the lowest combustion duration $\left(33.84{ }^{\circ} \mathrm{CA}\right) \mathrm{IP} 20$ fuel was 1.6 air excess coefficient and $800 \mathrm{rpm}$. has also been realized.

\subsubsection{Indicated thermal efficiency}

ANOVA results obtained for the indicated thermal efficiency are given in Table 14. As seen in the ANOVA table, the model created is meaningful and significant ( $p$-value $<0.0001$ ). Among the input parameters, engine speed and fuel type p-value is less than 0.05 . While the effect of engine speed and fuel type on the indicated thermal efficiency is high, the air excess coefficient is not significant. When the F-value is examined, it is seen that the fuel type has a more important effect than the other input parameters.

Table 14. ANOVA table for indicated thermal efficiency (\%)

\begin{tabular}{c|c|c|c|c|c}
\hline Source & $\begin{array}{c}\text { Sum of } \\
\text { Sq. }\end{array}$ & $\begin{array}{c}\text { Mean S } \\
\mathbf{q} \cdot\end{array}$ & F-value & p-value & Remarks \\
\hline Model & 444,84 & 27,8 & 71,2 & $<0.0001$ & $\begin{array}{c}\text { significan } \\
\mathrm{t}\end{array}$ \\
\hline $\begin{array}{c}\mathrm{X}_{1} \text { - Engi } \\
\text { ne speed }\end{array}$ & 34,16 & 34,16 & 87,49 & $<0.0001$ & $\begin{array}{c}\text { significan } \\
\mathrm{t}\end{array}$ \\
\hline $\begin{array}{c}\mathrm{X}_{2} \text {-Lam } \\
\text { bda }\end{array}$ & 0,0462 & 0,0462 & 0,1184 & 0,7387 & $\begin{array}{c}\text { not signif } \\
\text { icant }\end{array}$ \\
\hline $\mathrm{X}_{3}$-Fuel & 83,95 & 83,95 & 214,98 & $<0.0001$ & $\begin{array}{c}\text { significan } \\
\mathrm{t}\end{array}$ \\
\hline Residual & 3,51 & 0,3905 & & & \\
\hline Cor Total & 448,36 & & & & \\
\hline
\end{tabular}

The correlation coefficient (R2) of the model created for the indicated thermal efficiency (\%) was 0.9922 and the adjusted correlation coefficient R2 (Adj. R2) was 0.9782. Since the difference between them is less than 0.02 , it shows that the created model is compatible. The quartic model Eq. 14 for the Indicated thermal efficiency (\%) by the response surface method.

$$
\begin{aligned}
\eta_{\mathrm{ITE}}(\%) & =40,16+2,923 X_{1}-2,690 X_{3}-1,883 X_{2} X_{3} \\
& -1,438 X_{2}^{2}+0,621 X_{1} X_{2} X_{3}+1,909 X_{1}^{2} X_{2} \\
& +2,583 X_{1}^{2} X_{3}-2,556 X_{1} X_{2}^{2}+0,853 X_{2}^{2} X_{3} \\
& -1,731 X_{1}^{2} X_{2}^{2}-3,204 X_{1}^{2} X_{2} X_{3}-1,334 X_{1} X_{2}^{2} X_{3}
\end{aligned}
$$

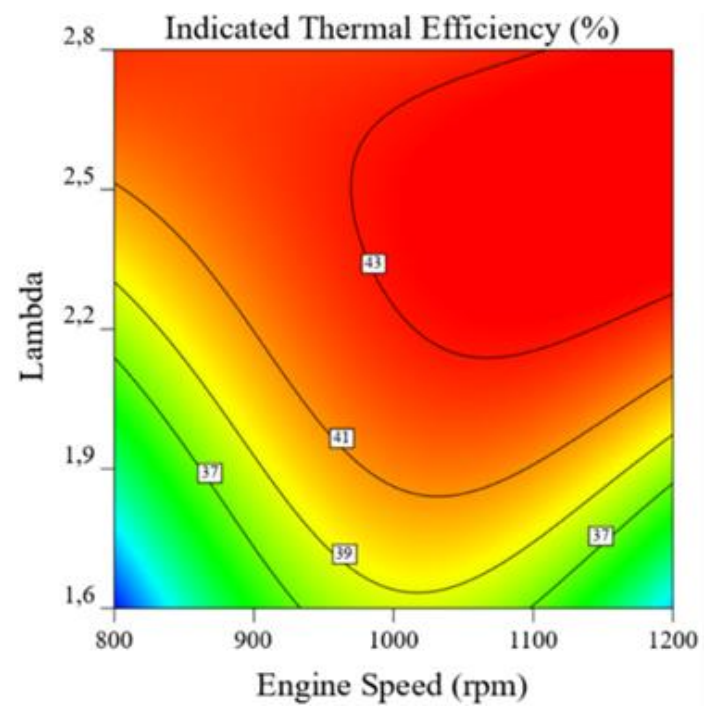

a) IP20

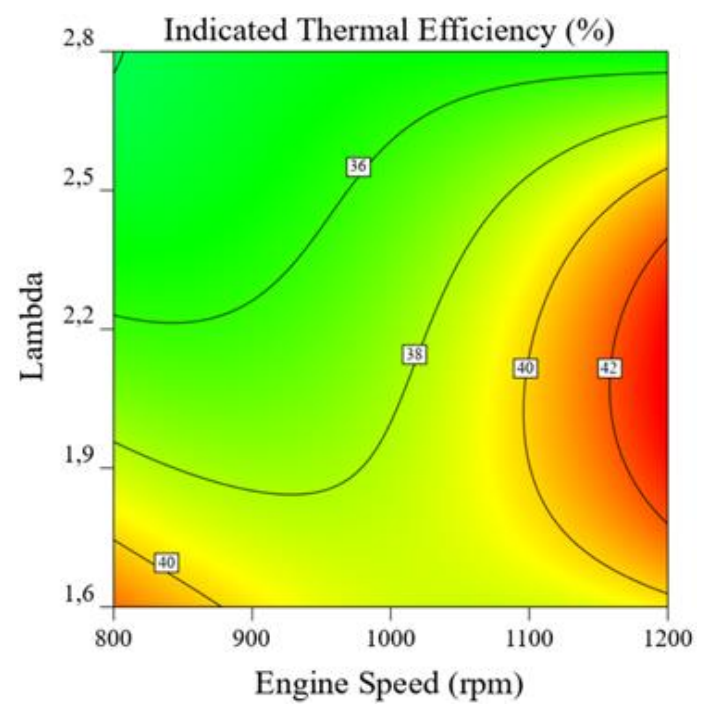

b) IP40

Figure 9. Effect of lambda and engine speed on indicated thermal efficiency $(a$ and $b)$

Figures $9 \mathrm{a}$ and $9 \mathrm{~b}$ show the indicated thermal efficiency values depending on the air excess coefficient and engine speed of the IP20 and IP40 test fuels, respectively. In the use of IP20 fuel, the occurrence of CA50 just after TDC has increased the indicated thermal efficiency. The highest indicated thermal efficiency for IP20 fuel was realized at $1200 \mathrm{rpm}$ motor speed with an air excess coefficient of 2.8 and the CA50 $7.02^{\circ} \mathrm{CA}$ after TDC. The indicated thermal efficiency here was $43.35 \%$. In the use of IP40 test fuel, the indicated thermal efficiency was lower than the IP20 test fuel because most of the combustion occurred in the expansion time. While the indicated thermal efficiency was $41.87 \%$ under conditions where CA50 was realized $8.64{ }^{\circ} \mathrm{CA}$ after TDC, it was realized $14.76{ }^{\circ} \mathrm{CA}$ after TDC 
CA50 in operating conditions where the air excess coefficient was 2.8 at $800 \mathrm{rpm}$ engine speed as a result of the depletion of the mixture. As a result of this situation, it caused the indicated thermal efficiency to decrease up to $34.21 \%$.

\subsection{Interaction Effects of Exhaust Emissions}

\subsubsection{Unburned hydrocarbon emissions (UHCs)}

ANOVA results for unburned hydrocarbon emissions are shown in Table 15. As seen in the ANOVA table, the model created is meaningful and significant ( $\mathrm{p}$-value $<0.0001$ ). The input parameters of engine speed, air excess coefficient and fuel type p-value are less than 0.05. All intake parameters have an impact on unburned hydrocarbon emissions. When analysed in terms of F-value, it is seen that engine speed has a more important effect than the other two input parameters.

Table 16. ANOVA table for unburned hydrocarbon emissions (ppm)

\begin{tabular}{c|c|c|c|c|c}
\hline Source & $\begin{array}{c}\text { Sum of } \\
\text { Sq. }\end{array}$ & $\begin{array}{c}\text { Mean S } \\
\text { q. }\end{array}$ & F-value & p-value & Remarks \\
\hline Model & 69865,27 & 4366,58 & 324,17 & $<0.0001$ & significant \\
\hline $\begin{array}{c}\mathrm{X}_{1} \text { - Engi } \\
\text { ne speed }\end{array}$ & 7744 & 7744 & 574,91 & $<0.0001$ & significant \\
\hline $\begin{array}{c}\mathrm{X}_{2} \text {-Lamb } \\
\text { da }\end{array}$ & 3844 & 3844 & 285,38 & $<0.0001$ & significant \\
\hline $\mathrm{X}_{3}$-Fuel & 1001,8 & 1001,8 & 74,37 & $<0.0001$ & significant \\
\hline Residual & 121,23 & 13,47 & & & \\
\hline Cor Total & 69986,5 & & & & \\
\hline
\end{tabular}

The correlation coefficient (R2) of the model created for unburned hydrocarbon emissions (ppm) was 0.9983 and the adjusted correlation coefficient R2 (Adj. R2) was 0.9952 . This result shows that the created model is compatible. The quartic model Eq. 15 for unburned hydrocarbon emissions (ppm) generated by the response surface method:

$$
\begin{gathered}
\operatorname{UHCs}(\mathrm{ppm})=370-44 X_{1}+31 X_{2}+9,293 X_{3}-19,125 X_{1} X_{2}-14 X_{1} X_{3}+5 X_{1}^{2}-8,5 X_{2}^{2} \\
-24,875 X_{1} X_{2} X_{3}+30,375 X_{1}^{2} X_{2}+24,474 X_{1}^{2} X_{3}+17,875 X_{1} X_{2}^{2} \\
-9,026 X_{2}^{2} X_{3}-12,625 X_{1}^{2} X_{2}^{2}+12,625 X_{1}^{2} X_{2} X_{3}+12,125 X_{1} X_{2}^{2} X_{3}
\end{gathered}
$$

$\mathrm{HC}$ emissions occur as an incomplete combustion product. Among the reasons for the formation of $\mathrm{HC}$ emissions, incomplete combustion air-fuel mixture in the regions close to the cylinder walls and the occurrence of incomplete combustion, especially at low engine speeds, depending on the operating conditions of the engine [39]. In HCCI engines, UHCs emissions are similar to those of the SI engine. In particular, UHCs emissions occur as a result of HCCI combustion at low temperature [40]. Figures 10a and 10b show the air excess coefficient of the IP20 and IP40 test fuels in the HCCI engine and unburned hydrocarbon values depending on the engine speed, respectively. As the air excess coefficient increases, it is seen that HC emissions increase all fuels [41]. This is because the amount of energy released as a result of combustion and the gas temperatures at the end of the combustion decrease with the depletion of the mixture. As the amount of isopropanol in the mixture fuels increased, $\mathrm{HC}$ emissions increased, the reason for this is the expansion of the volume as a result of the shift of the combustion to the expansion time and the slowdown of in-cylinder oxidation reactions. Comparing the results of the experiments conducted under the same conditions under the same conditions at $1200 \mathrm{rpm}$ engine speed, the test results were $308 \mathrm{ppm}$ in the IP20 test fuel, while it increased $14 \%$ in the IP40 test fuel and became $354 \mathrm{ppm}$.

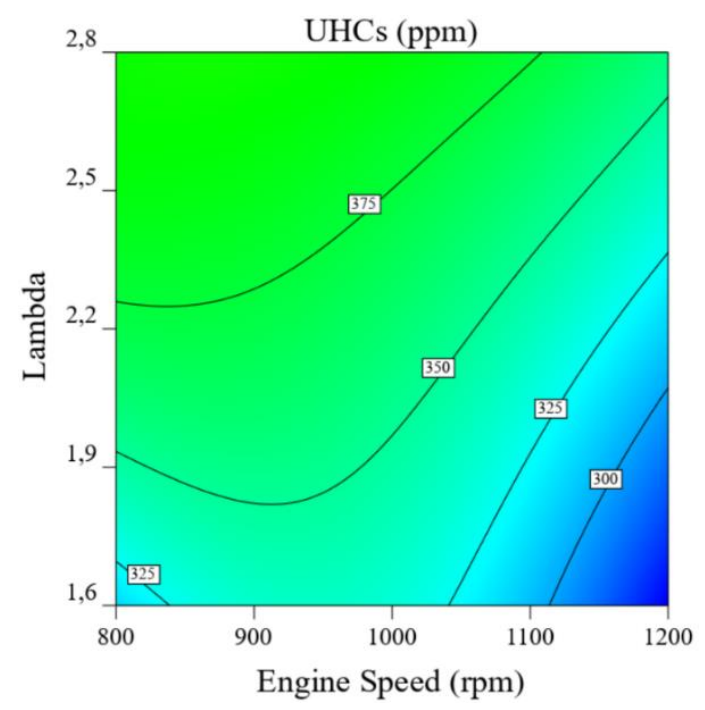

a) IP20

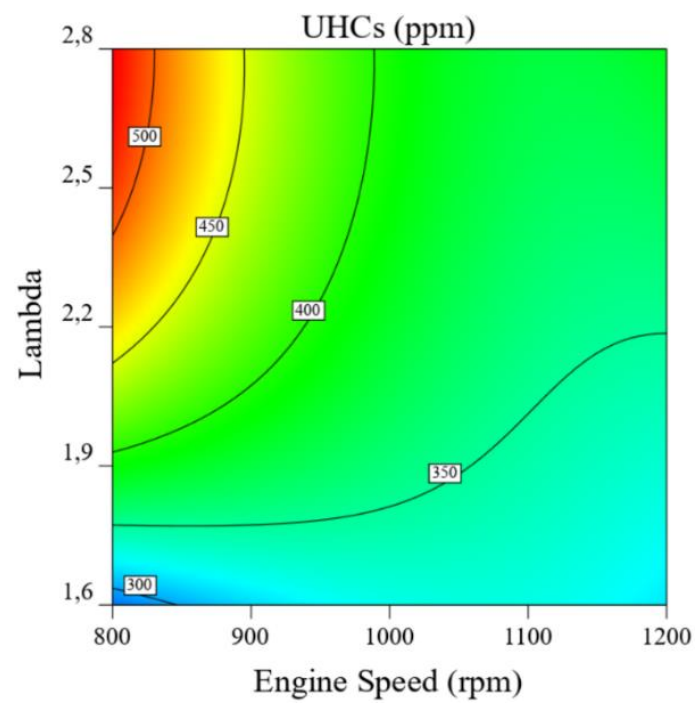

b) IP40

Figure 10. Effect of lambda and engine speed on $\operatorname{UHCs}(a$ and $b$ )

\subsubsection{Carbon monoxide emissions (CO)}

ANOVA results for carbon monoxide emissions are shown in Table 17. As seen in the ANOVA table, the model created is meaningful and significant ( $\mathrm{p}$-value $<0.0001$ ). The air excess coefficient and fuel type p-value, which are the inlet parameters, are less than 0.05. However, the $\mathrm{p}$-value of the engine speed is over 0.05 . Therefore, engine speed has no effect on carbon monoxide emissions. When 
examined in terms of the F-value, it is seen that the air excess coefficient has a more important effect.

Table 17. ANOVA table for carbon monoxide emissions (\%)

\begin{tabular}{c|c|c|c|c|c}
\hline Source & $\begin{array}{c}\text { Sum of } \\
\text { Sq. }\end{array}$ & $\begin{array}{c}\text { Mean S } \\
\mathbf{q} \text { - }\end{array}$ & F-value & p-value & Remarks \\
\hline Model & 0,2395 & 0,015 & 39,65 & $<0.0001$ & significant \\
\hline $\begin{array}{c}\mathrm{X}_{1} \text { - Engi } \\
\text { ne speed }\end{array}$ & 0,0019 & 0,0019 & 5,01 & 0,0519 & $\begin{array}{c}\text { not signif } \\
\text { icant }\end{array}$ \\
\hline $\begin{array}{c}\mathrm{X}_{2} \text {-Lamb } \\
\text { da }\end{array}$ & 0,0588 & 0,0588 & 155,81 & $<0.0001$ & significant \\
\hline $\mathrm{X}_{3}$-Fuel & 0,0231 & 0,0231 & 61,29 & $<0.0001$ & significant \\
\hline Residual & 0,0034 & 0,0004 & & & \\
\hline Cor Total & 0,2429 & & & & \\
\hline
\end{tabular}

The correlation coefficient (R2) of the model created for carbon monoxide emissions (\%) was 0.9860 and the adjusted correlation coefficient R2 (Adj. R2) value was 0.9661. This result shows that the created model is compatible. The quartic model Eq. (16) for carbon monoxide emissions (\%) generated by the response surface method:

$$
\begin{gathered}
\mathrm{CO}(\%)=0,209+0,121 X_{2}+0,045 X_{3}-0,082 X_{1}^{2} \\
+0,054 X_{1}^{2} X_{2}^{2}-0,028 X_{1} X_{2}^{2} X_{3}
\end{gathered}
$$

$\mathrm{CO}$ emissions are a type of emission that occurs when there is not enough oxygen in the cylinder or when oxidation reactions are disrupted due to low temperature. As can be seen from the ANOVA table, $\mathrm{CO}$ emissions are sensitively affected by the changes in the excess air coefficient. $\mathrm{CO}$ emissions are constantly increasing under rich mixture conditions where the excess air coefficient is low. However, even if there is sufficient oxygen in the cylinder under extremely lean mixing conditions, $\mathrm{CO}$ emissions increase again due to the low gas temperatures in the cylinder. The low temperature inside the cylinder prevents the conversion of $\mathrm{CO}$ to $\mathrm{CO} 2[6,42]$. Figures 11a and 11b, show the air excess coefficient of the IP20 and IP40 test fuels in the HCCI engine and carbon monoxide emission values depending on the engine speed, respectively. $\mathrm{CO}$ emissions increased with the depletion of the mixture in both test fuels. Comparing the results of the experiments conducted under the same conditions at an engine speed of $2200 \mathrm{rpm}$, the test results were $0.084 \%$ in the IP20 test fuel and $0.212 \%$ in the IP40 test fuel.

\subsubsection{Nitrogen oxide emissions $\left(\mathrm{NO}_{\mathrm{x}}\right)$}

ANOVA results for nitrogen oxide emissions are shown in Table 18. As seen in the ANOVA table, the model created is meaningful and important ( $p$-value $<0.0001$ ). The $p$-value of the air excess coefficient for the input parameter is less than 0.05 . However, the p-value of the engine speed and fuel type is over 0.05. Therefore, fuel type and engine speed have no effect on nitrogen oxide emissions.

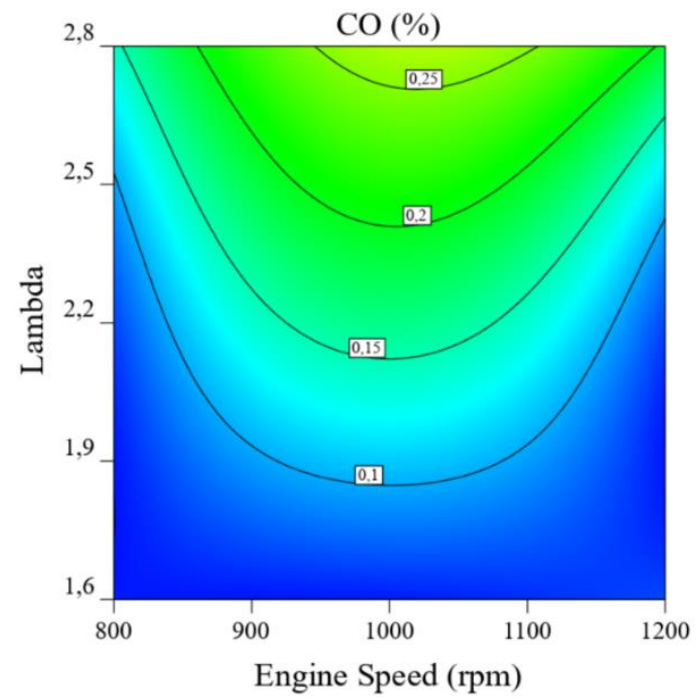

a) IP20

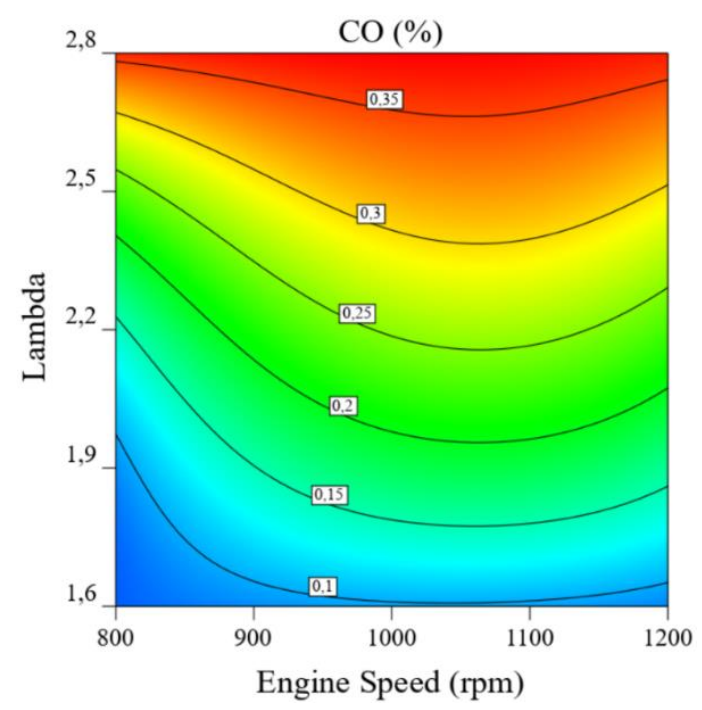

b) IP40

Figure 11. Effect of lambda and engine speed on $\mathrm{CO}(\mathrm{a}$ and $\mathrm{b})$

Table 18. ANOVA table for nitrogen oxide emissions (ppm)

\begin{tabular}{c|c|c|c|c|c}
\hline Source & $\begin{array}{c}\text { Sum of } \\
\text { Sq. }\end{array}$ & Mean Sq. & F-value & p-value & Remarks \\
\hline Model & 9691,83 & 605,74 & 21,29 & $<0.0001$ & significant \\
\hline $\begin{array}{c}\mathrm{X}_{1} \text { - En- } \\
\text { gine } \\
\text { speed }\end{array}$ & 0 & 0 & 0 & 10.000 & $\begin{array}{c}\text { not signif- } \\
\text { icant }\end{array}$ \\
\hline $\begin{array}{c}\mathrm{X}_{2}- \\
\text { Lambda }\end{array}$ & 169 & 169 & 5,94 & 0,0375 & significant \\
\hline $\mathrm{X}_{3}$-Fuel & 40,97 & 40,97 & 1,44 & 0,2608 & $\begin{array}{c}\text { not signif- } \\
\text { icant }\end{array}$ \\
\hline Residual & 256,06 & 28,45 & & & \\
\hline Cor Total & 9947,88 & & & & \\
\hline
\end{tabular}

The correlation coefficient (R2) of the model created for nitrogen 
oxide emissions (ppm) was 0.9743 and the adjusted correlation coefficient R2 (Adj. R2) was 0.9285. This result shows the created model within the boundaries. The quartic model Eq. (17) for nitrogen oxide emissions (ppm) generated by the response surface method:

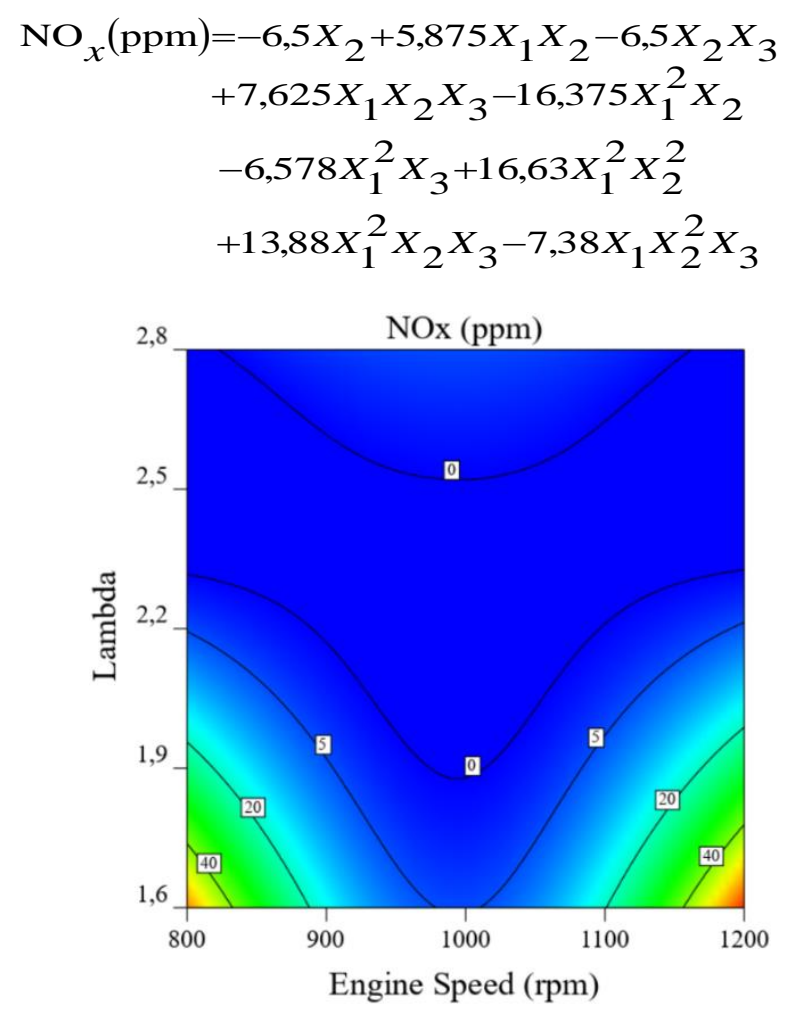

a) IP20

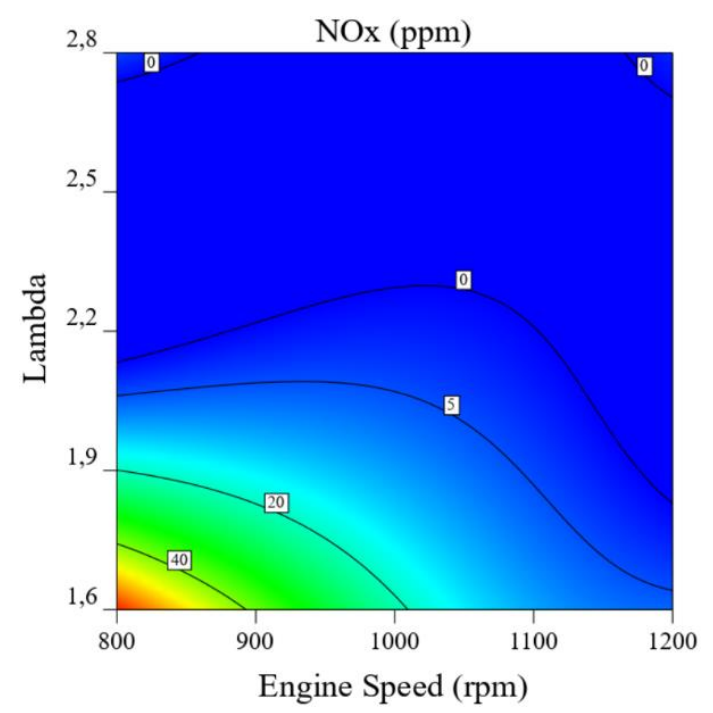

b) IP40

Figure 12. Effect of lambda and engine speed on $\operatorname{NOx}(a$ and $b)$

Reason for NOx emission formation is that the end-of-combustion temperature exceeds approximately 2073 K [43]. Figures 12a and $12 \mathrm{~b}$ show the nitrogen oxide emission values of the IP20 and IP40 test fuels, respectively, depending on the HCCI engine air excess co- efficient and engine speed. The reason for this is that the gas temperature in the cylinder is high, as the rich mixture has a better combustion and oxidation rate. However, it is seen that the amount of NOx emission decreases when the excess air ratio and engine speed values increase in both test fuels.


Figure 13. Predicted and Experimental values of Effective Torque, ITE,

$$
\text { IMEP, MPRR, COV IMEP }
$$

\subsection{Optimization and Validation}

In this study, engine speed, excess air coefficient and fuel type are used as input parameters. The response values predicted with the experimental data obtained in line with the experiments performed were optimized and verified. Optimization was made with the response surface methodology and the Design Expert 12 program was used. When the values shown in Fig. 13 and Fig. 14 are examined, the experimental data and the estimated data are almost exactly the same. Considering these results, it is seen that the model created is successful. The deviations in the graphs are quite low, since the R2 and adjusted R2 correlation values are in appropriate intervals in all responses. The high correlation values and the close experimental and estimated data proves the accuracy of the quartic equation used 
in the model.

As a result of the response surface methodology optimization, it is concluded that the optimum operating parameters are an engine speed of $1200 \mathrm{rpm}$ and an excess air ratio of 1.725 by using IP40test fuel. Response parameters under optimum operating conditions Effective Torque $11.438 \mathrm{Nm}$, IMEP $4.366 \mathrm{bar}$, MPRR $2.747 \mathrm{bar} /{ }^{\circ} \mathrm{CA}$, COVIMEP 4.364\%, CA10 2.315 ${ }^{\circ} \mathrm{CA}$, CA50 $7{ }^{\circ} \mathrm{CA}, \mathrm{CA} 10-\mathrm{CA} 90$ $36.245^{\circ} \mathrm{CA}$, UHCs $324.562 \mathrm{ppm}$, CO 0.0118\% and NOx $2.549 \mathrm{ppm}$ were determined. The results obtained in the MPRR, COVIMEP and CA50 responses were within the target range. The desirability value of this optimization was found to be 0.857 . The fact that the result is close to 1.000 shows that the optimization made is compatible with the experimental study.

In order to run the engine's responses with the desired data, the optimum input parameters must be determined. One of the most important factors in determining the optimum input parameters is the establishment of optimization criteria. Optimization criteria are given in Table 19. The input parameter values were determined as 800-1200 rpm for the motor speed, 1.6 - 2.8 for the excess air ratio value and $20 \%$ and $40 \%$ for the isopropanol density in the heptane (IP20-IP40). Among the targeted response parameters, IMEP, effective torque and thermal efficiency values are aimed to be maximum, while $\mathrm{HC}, \mathrm{CO}$ and NOx emission values are aimed to be minimum. MPRR values are at acceptable levels between $1-8\left(\mathrm{bar} /{ }^{\circ} \mathrm{CA}\right)$ and COVIMEP values are $1-6(\%)$ It is aimed that the CA50 value, which directly affects the effective torque and the indicated thermal efficiency value, is between 7 - $11\left({ }^{\circ} \mathrm{CA}\right)$.

Table 19. Respond Surface Methodology optimization criteria

\begin{tabular}{c|c|c|c|c}
\hline \multirow{2}{*}{ Parameter } & \multirow{2}{*}{ Approach } & \multicolumn{2}{|c|}{ Limits } & \multirow{2}{*}{ Importance } \\
\cline { 3 - 4 } & & Lower & Upper & \\
\hline $\begin{array}{c}\text { Engine } \\
\text { speed }\end{array}$ & in range & 800 & 1200 & 3 \\
\hline Lambda & in range & 1,6 & 2,8 & 3 \\
\hline Fuel & in range & 20 Izo & 40 Izo & 3 \\
\hline $\begin{array}{c}\text { Effective } \\
\text { Torque }\end{array}$ & maximize & 3 & 12,4 & 3 \\
\hline IMEP & maximize & 1,69452 & 4,63569 & 3 \\
\hline MPRR & in range & 1 & 8 & 3 \\
\hline COVimep & in range & 1 & 6 & 3 \\
\hline CA10 & none & $-1,8$ & 6,84 & 3 \\
\hline CA50 & in range & 7 & 11 & 3 \\
\hline $\begin{array}{c}\text { CA10- } \\
\text { CA90 }\end{array}$ & none & 33,84 & 41,4 & 3 \\
\hline $\begin{array}{c}\text { Indicated } \\
\text { Thermal Ef- } \\
\text { ficiency }\end{array}$ & maximize & 27,14 & 43,35 & 3 \\
\hline HC & minimize & 255 & 526 & 3 \\
\hline CO & minimize & 0,044 & 0,371 & 3 \\
\hline NOx & minimize & 0 & 64 & 3 \\
\hline
\end{tabular}
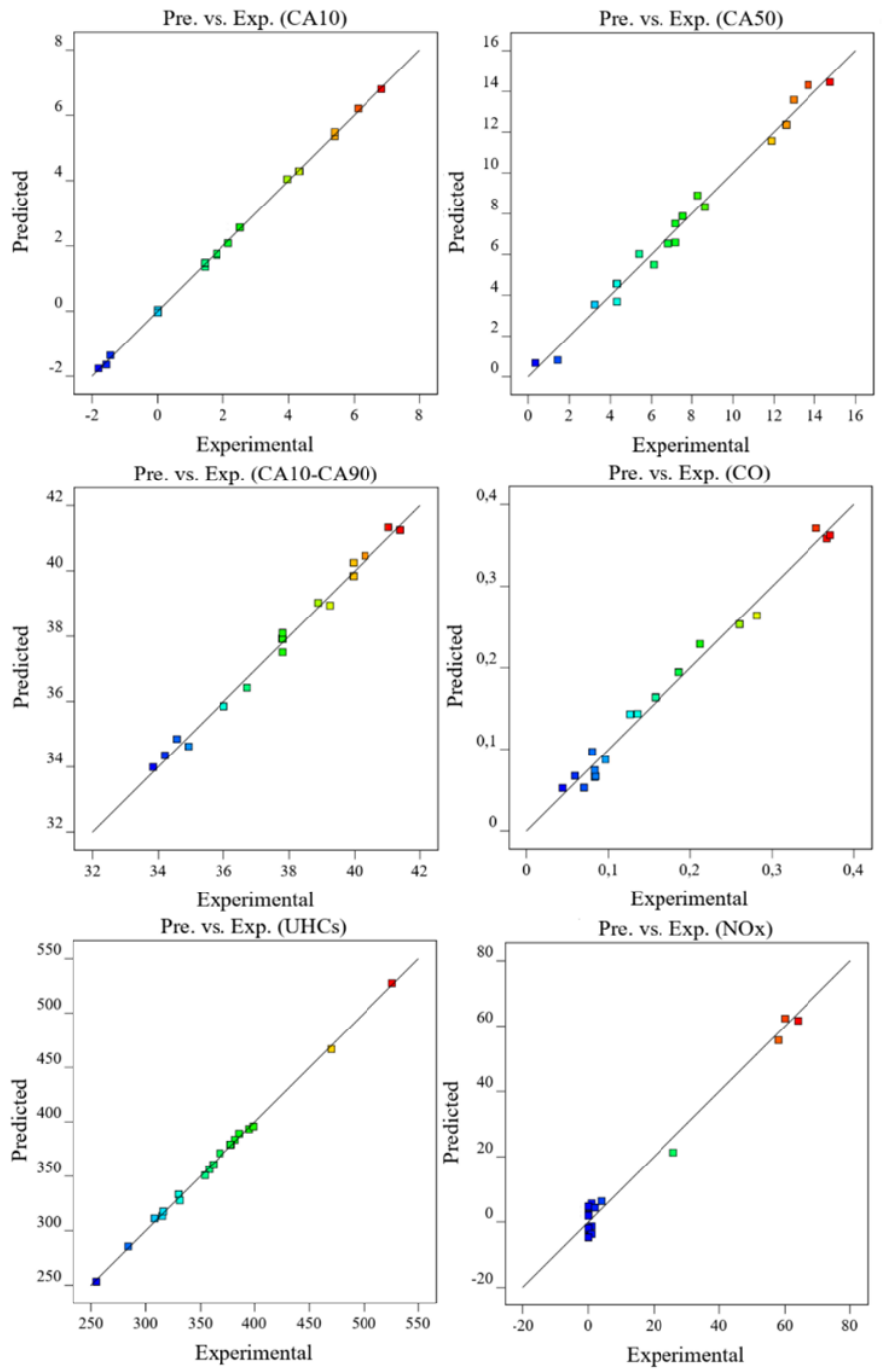

Figure 14. Predicted and Experimental values of CA10, CA50, CA10CA90, UHCs, CO, NOx

\section{Conclusions}

The dates of manuscript received, revised and accepted will be In this study, the effect of isopropanol heptane mixture test fuels (IP20 and IP40) on combustion and exhaust emissions at constant intake air inlet temperature $\left(60{ }^{\circ} \mathrm{C}\right)$ at different engine speed $(800 \mathrm{rpm}$ $1200 \mathrm{rpm}$ ) and air excess coefficient (1.6 - 2.8) in an HCCI engine. The aim is to determine the optimum input parameters required to obtain the appropriate response parameters by analysing and optimizing with the response surface method. With this research, effective torque, indicated mean effective pressure, indicated thermal efficiency, maximum pressure increase rate, COVIMEP, CA10, CA50, CA10-CA90 values and $\mathrm{HC}, \mathrm{CO}$ and NOx emissions were determined as response parameters. Engine speed, excess air ratio and isopropanol in fuel. It has been observed that the effective torque and the indicated thermal efficiency values increase with the increase of the input parameters. The increase in the input parameters caused the CA50 value to approach the targeted values. Also, the addition of isopropanol to n-heptane fuel caused the working range to narrow. The main reason for this is which, due to the high-octane number of 
isopropanol, combustion is delayed and most of the heat dissipation occurs in the expansion time. The maximum effective torque value of the engine used was obtained as $12.4 \mathrm{Nm}$ at 2,8 air excess coefficient at $1200 \mathrm{rpm}$ by using IP40 test fuel. Maximum indicated thermal efficiency value in IP20 test fuel use was found as $43.35 \%$ at $1200 \mathrm{rpm}$ engine speed and 2.8 excess air ratio value conditions. When the value of indicated air pressure was examined, the maximum indicated air pressure value was found as 1.6 air excess coefficient at $1200 \mathrm{rpm}$ using IP40 test fuel as 4.64 bar. For the maximum pressure rise rate (MPRR), as the air excess coefficient decreased, that is, as the mixture got richer, the maximum pressurise rate increased. The high-octane number of isopropanol slowed the combustion and kept the pressure increase rate below the critical level. At $1000 \mathrm{rpm}$ conditions where the air excess coefficient is 1.6, the pressure increase rate of IP20 and IP40 fuels is approximately 10.52 bar $/{ }^{\circ} \mathrm{CA}$, while IP20 and IP40 are $1.2095 \mathrm{bar} /{ }^{\circ} \mathrm{CA}$ and $0.8416 \mathrm{bar}$, respectively, when the air excess coefficient is 2.8 under the same conditions. While the COVIMEP value is higher in IP40 test fuel, it decreases in IP20 test fuel. In the use of IP20 test fuel, the start of combustion and started later than IP40 fuel. Due to its high-octane number, the place of CA50 in IP40 fuel starts later than IP20. The combustion duration is expressed with the CA10-CA90 value. In the use of IP40 test fuel, the combustion shifted to the expansion time and lasted quite long. With IP20 fuel, the highest indicated thermal efficiency was obtained at high air excess coefficient values. The highest indicated thermal efficiency was recorded as $43.35 \%$ in the use of IP20 fuel under conditions where the air excess coefficient at $1200 \mathrm{rpm}$ is 2.8. Increasing the concentration of isopropanol in the test fuel mixture causes the combustion to shift mostly to the expansion time under lean mixture conditions. Therefore, the temperatures at the end of combustion decreased and $\mathrm{CO}$ and $\mathrm{HC}$ emissions increased simultaneously in engine speeds and fuel types with high air excess coefficient. NOx emission, which is generally measured as 0 , has increased in the regions where the mixture is rich. It is seen that it is appropriate to use isopropanol as fuel in HCCI engines with high compression ratio. According to the optimization results of the experimental data, the desirability value was obtained as 0.857 .

\section{Conflict of Interest Statement}

The authors declare that there is no conflict of interest in this study.

\section{CRediT Author Statement}

Seyed Mohammad Safieddin Ardebili: Supervision, Methodology, Writing-original draft; Çağatay Nacak: Application of RSM, Writing-original draft; Tolga Kocakulak: Experimental set-up, Writing-original draft; Mustafa Babagiray: Experimental set-up, Conceptualization, Writing-original draft

\section{References}

1. Lü, X., Ji, L., Zu, L., Hou, Y., Huang, C., and Huang, Z. (2007) Experimental study and chemical analysis of n-heptane homogeneous charge compression ignition combustion with port injection of reaction inhibitors. Combustion and flame. 149(3): p. 261-270.

2. Li, Y., Chen, Y., Wu, G., and Liu, J. (2018) Experimental evaluation of water-containing isopropanol-n-butanol-ethanol and gasoline blend as a fuel candidate in spark-ignition engine. Applied Energy. 219: p. 4252.

3. Polat, S., Solmaz, H., Y1lmaz, E., Calam, A., Uyumaz, A., and Yücesu, H.S. (2020) Mapping of an HCCI engine using negative valve overlap strategy. Energy Sources, Part A: Recovery, Utilization, and Environmental Effects. 42(9): p. 1140-1154.

4. Uyaroğlu, A., Gürü, M., Kocakulak, T., Uyumaz, A., and Solmaz, H. (2021) Combustion, performance and emission analyses of organic Manganese-Added crambe abyssinica biodiesel in a direct injection diesel engine. Fuel. 297: p. 120770.

5. An, Y., Jaasim, M., Raman, V., Pérez, F.E.H., Sim, J., Chang, J., Im, H.G., and Johansson, B. (2018) Homogeneous charge compression ignition (HCCI) and partially premixed combustion (PPC) in compression ignition engine with low octane gasoline. Energy. 158: p. 181-191.

6. Calam, A., Solmaz, H., Yılmaz, E., and İçingür, Y. (2019) Investigation of effect of compression ratio on combustion and exhaust emissions in A HCCI engine. Energy. 168: p. 1208-1216.

7. Aydoğan, B. (2021) Combustion, Performance and Emissions of Ethanol/n-Heptane Blends in HCCI Engine. Engineering Perspective. 1(1): p. 5.

8. Uyumaz, A., Aydoğan, B., Calam, A., Aksoy, F., and Y1lmaz, E. (2020) The effects of diisopropyl ether on combustion, performance, emissions and operating range in a HCCI engine. Fuel. 265: p. 116919.

9. Calam, A., Aydoğan, B., and Halis, S. (2020) The comparison of combustion, engine performance and emission characteristics of ethanol, methanol, fusel oil, butanol, isopropanol and naphtha with n-heptane blends on HCCI engine. Fuel. 266: p. 117071.

10. Polat, S., Yücesu, H.S., Solmaz, H., Uyumaz, A., Kannan, K., and Shahbakhti, M. (2019) An Experimental Study on the Variation of COVIMEP and Ringing Intensity at Different Air Excess Coefficients in a HCCI Engine, in International Symposium on Automotive Science and Technology-2019: Ankara, Turkey.

11. Solmaz, H., Ardebili, S.M.S., Calam, A., Y1lmaz, E., and İpci, D. (2021) Prediction of performance and exhaust emissions of a CI engine fueled with multi-wall carbon nanotube doped biodiesel-diesel blends using response surface method. Energy. p. 120518.

12. Bahng, G., Jang, D., Kim, Y., and Shin, M. (2016) A new technology to overcome the limits of HCCI engine through fuel modification. Applied Thermal Engineering. 98: p. 810-815.

13. Elzahaby, A.M., Elkelawy, M., Bastawissi, H.A.-E., El_Malla, S.M., and Naceb, A.M.M. (2018) Kinetic modeling and experimental study on the combustion, performance and emission characteristics of a PCCI engine fueled with ethanol-diesel blends. Egyptian Journal of Petroleum. 27(4): p. 927-937.

14. Elkelawy, M., Yu-Sheng, Z., Hagar, A.E.-D., and Yu, J.-Z. (2008) Challenging and future of homogeneous charge compression ignition engines; an advanced and novel concepts review. Journal of power and energy systems. 2(4): p. 1108-1119.

15. Taghavifar, H., Nemati, A., and Walther, J.H. (2019) Combustion and exergy analysis of multi-component diesel-DME-methanol blends in HCCI engine. Energy. 187: p. 115951.

16. Bastawissi, H.A.E., Elkelawy, M., Panchal, H., and Sadasivuni, K.K. (2019) Optimization of the multi-carburant dose as an energy source for the application of the HCCI engine. Fuel. 253: p. 15-24.

17. Gainey, B., Yan, Z., and Lawler, B. (2021) Autoignition characterization of methanol, ethanol, propanol, and butanol over a wide range of operating conditions in LTC/HCCI. Fuel. 287: p. 119495. 
18. Uyumaz, A. (2015) An experimental investigation into combustion and performance characteristics of an HCCI gasoline engine fueled with nheptane, isopropanol and n-butanol fuel blends at different inlet air temperatures. Energy Conversion and Management. 98: p. 199-207.

19. Calam, A. and Aydoğan, B. (2019) Experimental Investigation of Performance Combustion and Emission Characteristics in an HCCI Engine Fuelled Isopropanol and Heptane Fuel Mixtures. Gazi Üniversitesi Fen Bilimleri Dergisi Part C. 7(4): p. 818-833.

20. Awad, O.I., Mamat, R., Ali, O.M., Azmi, W., Kadirgama, K., Yusri, I., Leman, A., and Yusaf, T. (2017) Response surface methodology (RSM) based multi-objective optimization of fusel oil-gasoline blends at different water content in SI engine. Energy Conversion and Management. 150: p. 222-241.

21. Mahla, S.K., Safieddin Ardebili, S.M., Mostafaei, M., Dhir, A., Goga, G., and Chauhan, B.S. (2020) Multi-objective optimization of performance and emissions characteristics of a variable compression ratio diesel engine running with biogas-diesel fuel using response surface techniques. Energy Sources, Part A: Recovery, Utilization, and Environmental Effects. p. 1-18.

22. Calam, A., İçingür, Y., Solmaz, H., and Yamık, H. (2015) A comparison of engine performance and the emission of fusel oil and gasoline mixtures at different ignition timings. International journal of green energy. 12(8): p. 767-772.

23. Awad, O.I., Ali, O.M., Mamat, R., Abdullah, A., Najafi, G., Kamarulzaman, M., Yusri, I., and Noor, M. (2017) Using fusel oil as a blend in gasoline to improve SI engine efficiencies: A comprehensive review. Renewable and Sustainable Energy Reviews. 69: p. 1232-1242.

24. Myers, R.H., Montgomery, D.C., Vining, G.G., Borror, C.M., and Kowalski, S.M. (2004) Response surface methodology: a retrospective and literature survey. Journal of quality technology. 36(1): p. 53-77.

25. Myers, R.H., Khuri, A.I., and Carter, W.H. (1989) Response surface methodology: 1966-1988. Technometrics. 31(2): p. 137-157.

26. Xiao, M., Shen, X., Ma, Y., Yang, F., Gao, N., Wei, W., and Wu, D. (2018) Prediction of surface roughness and optimization of cutting parameters of stainless steel turning based on RSM. Mathematical Problems in Engineering. 2018.

27. Li, Y., Meng, L., Nithyanandan, K., Lee, T.H., Lin, Y., Chia-fon, F.L., and Liao, S. (2016) Combustion, performance and emissions characteristics of a spark-ignition engine fueled with isopropanol-n-butanolethanol and gasoline blends. Fuel. 184: p. 864-872.

28. Halis, S., Nacak, Ç., Solmaz, H., Yilmaz, E., and Yucesu, H.S. (2018) Investigation of the effects of octane number on combustion characteristics and engine performance in a HCCI engine. Journal of Thermal Science and Technology. 38(2): p. 73-84.

29. Calam, A. and İçingür, Y. (2019) Hava fazlalık katsayısı ve oktan sayısı değişiminin HCCI yanma karakteristiklerine ve motor performansına etkileri. Politeknik Dergisi. 22(3): p. 607-618.

30. Xingcai, L., Yuchun, H., Libin, J., Zu Linlin, a., and Zhen, H. (2006) Heat release analysis on combustion and parametric study on emissions of HCCI engines fueled with 2-propanol/n-heptane blend fuels. Energy $\&$ fuels. 20(5): p. 1870-1878.

31. Bendu, H. and Murugan, S. (2014) Homogeneous charge compression ignition (HCCI) combustion: Mixture preparation and control strategies in diesel engines. Renewable and Sustainable Energy Reviews. 38: p. $732-746$.

32. Aydoğan, B. and Calam, A. (2020) Combustion, performance and emission caracteristics of a HCCI engine fuelled with n-butanol/n-heptane blends. International Journal of Automotive Engineering and Technologies. 9(1): p. 1-10.

33. Canakci, M. (2012) Combustion characteristics of a DI-HCCI gasoline engine running at different boost pressures. Fuel. 96: p. 546-555.

34. Maurya, R.K. and Agarwal, A.K. (2014) Experimental investigations of performance, combustion and emission characteristics of ethanol and methanol fueled HCCI engine. Fuel processing technology. 126: p. 30-48.

35. Halbe, M.H., Fain, D.J., Shaver, G.M., Kocher, L., and Koeberlein, D. (2017) Control-oriented premixed charge compression ignition CA50 model for a diesel engine utilizing variable valve actuation. International Journal of Engine Research. 18(8): p. 847-857.

36. Hakansson, A. (2007) CA50 estimation on HCCI engine using engine speed variations. Lund University: MSc Thesis.

37. Calam, A. (2021) Homojen Dolgulu Sıkıştırma ile Ateşlemeli Bir Motorda n-heptan-Tetrahidrofuran Karışımlarının Yanma, Performans ve Emisyonlara Etkisi. Politeknik Dergisi. p. 1-1.

38. Wang, Z., Liu, H., Ma, X., Wang, J., Shuai, S., and Reitz, R.D. (2016) Homogeneous charge compression ignition (HCCI) combustion of polyoxymethylene dimethyl ethers (PODE). Fuel. 183: p. 206-213.

39. Zhao, H. (2007) HCCI and CAI engines for the automotive industry. Elsevier.

40. Zheng, Z. and Yao, M. (2009) Charge stratification to control HCCI: Experiments and CFD modeling with n-heptane as fuel. Fuel. 88(2): p. 354-365.

41. Bendu, H., Deepak, B., and Murugan, S. (2016) Application of GRNN for the prediction of performance and exhaust emissions in HCCI engine using ethanol. Energy conversion and management. 122: p. 165173.

42. Jun, D. and Iida, N. (2004) A study of high combustion efficiency and low $\mathrm{CO}$ emission in a natural gas HCCI engine. SAE transactions. p. 1306-1316.

43. Dec, J.E. and Yang, Y. (2010) Boosted HCCI for high power without engine knock and with ultra-low NOx emissions-using conventional gasoline. SAE International Journal of Engines. 3(1): p. 750-767. 